\title{
Mitochondrial Dysfunction in Aging Rat Brain Regions upon Chlorpyrifos Toxicity and Cold Stress: An Interactive Study
}

\author{
P. Mahaboob Basha $\cdot$ Annappa Poojary
}

Received: 20 February 2014/ Accepted: 30 March 2014/Published online: 18 April 2014

(C) Springer Science+Business Media New York 2014

\begin{abstract}
Mitochondrial dysfunction and consequent energy depletion are the major causes of oxidative stress resulting to bring alterations in the ionic homeostasis causing loss of cellular integrity. Our previous studies have shown the age-associated interactive effects in rat central nervous system (CNS) upon co-exposure to chlorpyrifos (CPF) and cold stress leading to macromolecular oxidative damage. The present study elucidates a possible mechanism by which $\mathrm{CPF}$ and cold stress interaction cause(s) mitochondrial dysfunction in an age-related manner. In this study, the activity levels of Krebs cycle enzymes and electron transport chain (ETC) protein complexes were assessed in the isolated fraction of mitochondria. CPF and cold stress $\left(15\right.$ and $\left.20{ }^{\circ} \mathrm{C}\right)$ exposure either individually or in combination decreased the activity level of Krebs cycle enzymes and ETC protein complexes in discrete regions of rat CNS. The findings confirm that cold stress produces significant synergistic effect in CPF intoxicated aging rats. The synergism between $\mathrm{CPF}$ and cold stress at $15{ }^{\circ} \mathrm{C}$ caused a higher depletion of respiratory enzymes in comparison with $\mathrm{CPF}$ and cold stress alone and together at $20{ }^{\circ} \mathrm{C}$ indicating the extent of deleterious functional alterations in discrete regions of brain and spinal cord (SC) which may result in neurodegeneration and loss in neuronal metabolic control. Hence, co-exposure of CPF and cold stress is more dangerous than exposure of either
\end{abstract}

P. M. Basha $(\square)$

Department of Zoology, Bangalore University,

Bangalore 560 056, India

e-mail: pmbashabub@rediffmail.com

\section{A. Poojary}

Department of Zoology, Govt. Women's College,

Kolar 563 101, Karnataka, India

e-mail: annu1967@gmail.com alone. Among the discrete regions studied, the cerebellum and medulla oblongata appears to be the most susceptible regions when compared to cortex and SC. Furthermore, the study reveals a gradual decrease in sensitivity to $\mathrm{CPF}$ toxicity as the rat matures.

Keywords Chlorpyrifos - Cold stress - Aging rats · Mitochondria $\cdot$ Krebs cycle $\cdot$ ETC complex

\section{Introduction}

Brain is the post-mitotic vital organ, controlling and coordinating the activities of other organs and their respective functions. Being highly active organ, its activity rhythms shown to be altered with the changes in the external environment as well as in the internal milieu, and its high energy demand is particularly dependent on mitochondria (Du et al. 2008). It is highly susceptible to free radical attack because it generates more toxic radicals than any other organ (Richter et al. 1995). Central nervous system (CNS) depends heavily on ATP production that the inhibition of oxidative phosphorylation is shown to affect this system before any other system. Mitochondria preserve the cellular energy reserves with the ATP production as a result of two closely coordinated metabolic processes-the tricarboxylic acid (TCA) cycle and the electron transport chain (ETC). In the process of oxidative phosphorylation, electrons generated from the oxidation of fuel molecules by oxygen are passed along a transport chain that consists of four respiratory enzyme complexes in the mitochondrial inner membrane, leading to the generation of ATP from ADP (Hatefi 1985).

Organophosphate (OP) compounds being potent acetylcholine esterase (AChE) inhibitors are shown to inhibit 
mitochondrial enzymes (Moussa et al. 2008) and their exposure in non-target animals are shown to induce perturbations leading to death. Chlorpyrifos (CPF) toxicity has been largely associated with irreversible inhibition of AChE resulting in accumulation of ACh (LukaszewiczHussain 2010; Eaton et al. 2008). However, other putative mechanisms have been implicated as molecular mechanisms of CPF toxicity, among these; the induction of oxidative stress (Ambali et al. 2007) and protein oxidation has received higher attention. Our previous studies (Basha and Poojary 2011, 2012) have shown the age-associated interactive effects in rat CNS upon co-exposure to CPF and cold stress leading to macromolecular oxidative damage. In addition, inhibition of mitochondrial ATP production through the uncoupling of oxidative phosphorylation has been shown as a mechanism through which excessive production of ROS take place (Ishii et al. 2004).

Cold stress has been shown to cause histological, metabolic/enzymatic, and structural alterations in many organs of an animal (Smith and Hoijer 1962), leading to a sequence of metabolic events (Rajman et al. 2006). It has been reported that cold stress in human beings commonly occur in clammy weather, and is closely connected with cardiovascular and respiratory diseases, thereby causing higher mortality, especially among the elderly people (Mackenbach et al. 1992). It also plays a considerable role either in accelerating or modifying the toxic mechanisms and induces oxidative damage to several tissues by altering antioxidant status, protein oxidation, and lipid peroxidation (Sahin and Gumuslu 2004). Earlier studies of Maquire and Williams (1996) have reported that the cold stress enhances brain AChE inhibition induced by CPF in Northern bobwhites. Cold stress has also been shown to boast variable modulatory effects on blood biochemical parameters and enzymes (Obut et al. 2009; Hong et al. 2008).

Currently, there is a significant concern and focus over the potential sensitivity of developing and juvenile animals to the toxic effects of agrochemicals. Age-dependant changes in neonatal, juvenile, and young adult physiology (i.e. body size, blood flow, organ functions) and metabolic capacity may significantly impact their response to toxic insult (Basha and Poojary 2011, 2012). Earlier studies have established a relationship between the relative toxicity of OP compounds and their maturational expression of detoxification process (Karanth and Pope 2000). Further, CPF exposure in children is known to have serious impact on the developing brain (Rauh et al. 2006). Many studies using different routes of CPF administration have reported higher vulnerability in younger rats (Atterberry et al. 1997) while the reasons for the greater susceptibility is not explicated so far. Laboratory evidences, obtained largely through the use of rodents, suggest that acute or chronic exposure to $\mathrm{CPF}$ and/or its metabolic product(s) may overtly injure the CNS or produce marked changes in the neuronal function that persist even after the cessation of exposure, particularly during the early postnatal period (Slotkin et al. 2001). Understanding the potential of agerelated sensitivity to CPF toxicity is especially important in light of data suggesting greater exposure of children to pesticides (Boon et al. 2008).

The toxicity of OP compounds in non-target animals appears to antagonize or potentiate when they are exposed to low temperatures. While mitochondria easily succumb to diverse assaults either generated in situ or those imposed from extracellular environment (Hatefi 1985), mitochondrial dysfunction upon toxic insults might result in a dwindling supply of cellular energy, a failure in maintaining cellular homeostasis, and activation of cell death (Du et al. 2008). In spite of the extensive use of CPF for crop protection and in the household, information related to its interaction with cold stress, and resulted effects on health with particular reference to neurotoxicity are scarcely available. Since the co-exposure can result in antagonistic or synergistic effects, studies on their interactions will be of immense use to understand the realistic situation in the field especially on non-target organisms, hence this study was carried out to evaluate the age-dependent alterations in mitochondrial enzymes in discrete regions of CNS of rat and also to correlate the results with the changes in the AChE activity levels.

\section{Materials and Methods}

\section{Chemicals}

A commercial grade CPF having $20 \%$ (w/v) organic solvent dimethyl sulphoxide (DMSO) marketed as "Darsban" procured from Lupin Agrochemicals Pvt. Ltd., Bharuch, Gujarat (India) was used in this study. The commercial formulation was selected because it would reflect the realistic situation in the field, and this product is extensively used for agricultural practices in India. The other chemicals were purchased from BDH and Sigma-Aldrich.

Animals

Male albino rats, Wistar strain (Rattus norvegicus albinus) of different age groups viz., neonatal (7-day old, 10-12 g wt), juvenile (21-day old, 35-40 g wt), and adult (90-day old, 160-180 g wt) were used throughout the experiment. Rats were procured from Sri Raghavendra Enterprises, Bangalore and acclimatized to laboratory conditions (12 h dark/light cycle at $28 \pm 1{ }^{\circ} \mathrm{C}$ ) for 1 week prior to the commencement of the experiment. They were maintained on standard rodent pellet diet and tap water 
ad libitum; in accordance with the guidelines of National Institute of Nutrition, ICMR, Hyderabad, and experimental protocol was approved by the Institutional Animal Ethical Committee, Bangalore University, Bangalore.

\section{Experimental Protocol}

Rats were divided into six groups: Group I: control group kept at the laboratory room temperature $\left(28 \pm 1^{\circ} \mathrm{C}\right)$; Group II: exposed to CPF at the laboratory temperature, $28 \pm 1{ }^{\circ} \mathrm{C}$; Group III: exposed to cold stress at $15^{\circ} \mathrm{C}$; Group IV: exposed to cold stress at $20^{\circ} \mathrm{C}$; Group V: exposed to $\mathrm{CPF}$ plus cold stress at $15^{\circ} \mathrm{C}$; Group VI: exposed to $\mathrm{CPF}$ plus cold stress at $20^{\circ} \mathrm{C}$. The number of animals in each group was six. The neonatal and juvenile animals were kept along with the dam and other littermates in order to avoid additional stress. CPF was administered via subcutaneous injection in DMSO, a vehicle appropriate for water-insoluble agents and already known not to affect the corresponding measures of brain development (Slotkin et al. 2006). The Groups II, V, and VI animals were injected subcutaneously with sub-lethal doses $\left(1 / 3\right.$ of $\left.\mathrm{LD}_{50}\right)$ of CPF in a volume of $1 \mathrm{ml} / \mathrm{kg}$ body weight (bw) dissolved in DMSO. The Groups I, III, and IV animals were injected with plain DMSO (vehicle controls). The $48 \mathrm{~h} \mathrm{LD}_{50}$ of CPF (EC $20 \%$ ) in rats by subcutaneous route was assessed by probit analysis method Finney (1971) and observed values were found to be 15,242 , and $510 \mathrm{mg} / \mathrm{kg}$ bw for 7-, 21-, and 90-day old age groups, respectively.

To induce cold stress, rats were housed in an acute cold stress apparatus (Colton BOD incubator) for $48 \mathrm{~h}$ on a $12 \mathrm{~h}$ light/12 h dark cycle with a built-in heater and cooler that could be controlled by self-timer. Rats were sacrificed by cervical dislocation $48 \mathrm{~h}$ after respective treatments and discrete regions like cerebral cortex (CC), cerebellum (CB), medulla oblongata (MO), and spinal cord (SC) were quickly separated and washed in ice cold $0.9 \%$ saline. The tissue homogenates were prepared by using appropriate buffer, and supernatant was stored at a temperature of $-20{ }^{\circ} \mathrm{C}$ and used for assay of Krebs cycle enzymes and ETC complexes in the mitochondrial fraction.

\section{Experimental Procedures}

\section{Isolation of Mitochondria}

To isolate mitochondria, discrete regions of brain and SC tissues $(1 \mathrm{~g})$ were homogenized in $10 \mathrm{ml}$ of $10 \mathrm{mM}$ Tris$\mathrm{HCl}$ buffer ( $\mathrm{pH} 7.40)$ having $230 \mathrm{mM}$ mannitol, $70 \mathrm{mM}$ sucrose, and $1.0 \mathrm{mM}$ EDTA in a Potter homogenizer with a Teflon pestle. The homogenate was centrifuged at $700 \times g$ for $10 \mathrm{~min}$ and the supernatant at $8,000 \times g$ for $10 \mathrm{~min}$ to extract pellet having mitochondria that were washed in the same conditions to obtain mitochondrial preparations (Navarro et al. 2005). The mitochondria thus obtained were stored in the same medium. The purity of the mitochondrial preparation was assessed by the activity of succinate dehydrogenase, SDH (Vrbacky et al. 2007) and verified by the expression of mitochondrial respiratory enzyme complex-IV, MRC-IV (Naithani et al. 2003). Protein concentrations in the mitochondrial extracts of brain tissues were determined by the method described by Lowry et al. (1951). The cytochrome-c oxidase (CCO, marker enzyme for MRC-IV) activity was measured by oxidation of the reduced cytochrome-c. The activity is defined as the first-order rate constant and is calculated from known concentration of ferrocytochrome- $c$ and the enzyme amount in the assay mixture. Mitochondrial frac-

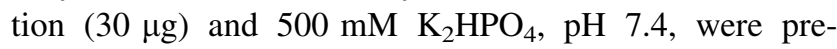
incubated at $30{ }^{\circ} \mathrm{C}$ for $5 \mathrm{~min} .100 \mu \mathrm{l}$ of $45 \mu \mathrm{M}$ ferrocytochrome- $c$ was added to start the reaction and monitored at $550 \mathrm{~nm}$ for $3 \mathrm{~min}$ at $30^{\circ} \mathrm{C}$. The background rate was measured after the addition of $1 \mu \mathrm{M} \mathrm{K}{ }_{3} \mathrm{Fe}(\mathrm{CN})_{6}$.

\section{TCA Cycle Enzymes}

Isocitrate dehydrogenase, ICDH (EC 1.1.1.41) activity was assayed according to the method given by King (1965). To

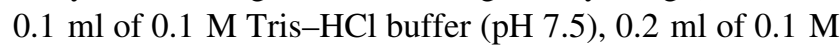
trisodium isocitrate, $0.3 \mathrm{ml}$ of $0.015 \mathrm{M} \mathrm{MnCl}_{2}, 0.2 \mathrm{ml}$ of $1 / 5$ diluted mitochondrial fraction, $0.2 \mathrm{ml}$ of $0.001 \mathrm{M}$ $\mathrm{NADP}^{+}$were added, and the volume was made up to $1.0 \mathrm{ml}$ by using double distilled water. The above mixture was incubated at room temperature for $1 \mathrm{~h}$. Then, $1 \mathrm{ml}$ of $0.001 \mathrm{M}$ 2,4-dinitrophenyl hydrazine was added followed by $0.5 \mathrm{ml}$ of $0.005 \mathrm{M}$ EDTA. The above mixture was incubated again at $37{ }^{\circ} \mathrm{C}$ for $20 \mathrm{~min}$. Further, $10 \mathrm{ml}$ of $0.4 \mathrm{~N} \mathrm{NaOH}$ was added, and the color developed was read spectrophotometrically at $540 \mathrm{~nm}$. The specific activity of the enzyme was expressed as "nmoles of a-ketoglutarate formed/min/mg protein".

\section{$S D H(E C$ 1.3.99.1)}

SDH activity was determined spectrophotometrically by measuring the decrease found in absorbance at $600 \mathrm{~nm}$ according to the method of Vrbacky et al. (2007). To $1 \mathrm{ml}$ of phosphate buffer ( $\mathrm{pH} 7.6$ ), $0.1 \mathrm{ml}$ of EDTA, $0.1 \mathrm{ml}$ of BSA, $0.1 \mathrm{ml}$ of sodium succinate, $2 \mathrm{ml}$ of water, and $0.1 \mathrm{ml}$ of potassium cyanide were added. To the above mixture, $0.2 \mathrm{ml}$ of $1 / 5$ diluted mitochondrial suspensions followed by $0.1 \mathrm{ml}$ of 2,6-dichlorophenol indophenols were added and mixed well, and the absorbance was measured spectrophotometrically at $600 \mathrm{~nm}$ immediately against a reagent blank without the mitochondrial fraction and chromogen. The extinction co-efficient of $21 \mathrm{mM}^{-1}$ / 
$\mathrm{cm}$ was used for calculation. The specific activity of the enzyme was expressed as "nmol of succinate oxidized/ $\mathrm{min} / \mathrm{mg}$ protein".

\section{Malate Dehydrogenase (EC 1.1.1.37)}

Malate dehydrogenase (MDH) activity was assayed by adopting the method given by Mehler et al. (1948). To $0.3 \mathrm{ml}$ of $0.25 \mathrm{M}$ Tris buffer ( $\mathrm{pH} 7.4$ ); $0.1 \mathrm{ml}$ of $0.0015 \mathrm{M}$ $\mathrm{NADH}$ and $0.0076 \mathrm{M}$ oxaloacetic acid added, and the volume was made up to $2.5 \mathrm{ml}$ with distilled water. To the above suspension, $0.1 \mathrm{ml}$ of $1 / 5$ diluted mitochondrial fraction added, and the decrease found in absorbance was measured at $340 \mathrm{~nm}$ for $5 \mathrm{~min}$ at $15 \mathrm{~s}$ interval in a spectrophotometer. The enzyme activity was expressed as "nmoles of NADH oxidized/min/mg of protein".

\section{Citrate Synthase (E.C. 2.3.3.1)}

Citrate synthase, CS (previously 4.1.3.7) activity was measured by adopting the method given by Srere (1969). Aliquots of mitochondria suspension were added to a medium containing $0.1 \mathrm{mM}$ acetyl-CoA, $0.2 \mathrm{mM}$ dithionitrobenzoic acid, and $100 \mathrm{mM}$ Tris- $\mathrm{HCl}$ buffer, $\mathrm{pH} 8.0$. Changes found in the absorbance at $412 \mathrm{~nm}$ were monitored in a spectrophotometer. The observations were recorded initially for $3 \mathrm{~min}$ at $15 \mathrm{~s}$ interval to obtain the activity of acetyl-CoA deacylase. Then, the enzyme reaction was started with addition of $0.2 \mathrm{mM}$ oxaloacetate and further recoded for $3 \mathrm{~min}$ at $15 \mathrm{~s}$ interval. The extinction co-efficient of $13.6 \mathrm{mM}^{-1} / \mathrm{cm}$ was used for the calculation of enzyme activity. The enzyme activity was expressed as "nmoles of dinitrobenzoic acid formed $/ \mathrm{min} / \mathrm{mg}$ of protein".

\section{Aconitate Hydratase (EC 4.2.1.3)}

Aconitate hydratase or aconitase (Acn) activity was measured by adopting the method given by Racker (1950). For the assay, $0.05 \mathrm{ml}$ of mitochondrial suspension and $100 \mathrm{mM}$ Tris buffer ( $\mathrm{pH} 8.0$ ) were added to $50 \mathrm{mM}$ citrate to give a final volume of $1 \mathrm{ml}$. The reaction was followed for $3 \mathrm{~min}$ at $15 \mathrm{~s}$ interval in a spectrophotometer at $240 \mathrm{~nm}$. The molar extinction co-efficient of cis-aconitate $\left(3.6 \mathrm{mM}^{-1} / \mathrm{cm}\right)$ was used for the calculation. The enzyme activity was expressed as "nmoles of cis-aconitate formed/ $\mathrm{min} / \mathrm{mg}$ of protein".

\section{Fumarase (EC 4.2.1.2) Activity}

Fumarase (also called fumarate hydratase, FH) was assayed by adopting the method given by Kanarek and Hill (1964). The reaction was followed with the formation of fumarate from L-malate at $25.8{ }^{\circ} \mathrm{C}$ in the presence of $1 \%$ Triton $\mathrm{X}-100$. Changes found in the absorbance at $250 \mathrm{~nm}$ were monitored in a spectrophotometer. The extinction co-efficient of $2.4 \mathrm{mM}^{-1} / \mathrm{cm}$ was used for the calculation of enzyme activity. The enzyme activity was expressed as "nmoles of fumarate formed/min/mg of protein".

\section{ETC Complexes}

Complex I (NADH-CoQ Oxidoreductase) Complex I activity was assayed by adopting the modified procedure given by Hatefi and Rieske (1967). To $880 \mu$ l of double distilled water, $50 \mu \mathrm{l}$ of $1 \mathrm{M}$ phosphate buffer $(\mathrm{pH} 8.0$ ), $50 \mu \mathrm{l}$ of $1 \mathrm{mM} \mathrm{CoQ}$, and $12 \mu \mathrm{l}$ of $10 \mathrm{mM}$ NADH were added and mixed well. $50 \mu \mathrm{l}$ of $1 / 5$ diluted mitochondrial fraction was added, and the decrease found in absorbance was measured at $340 \mathrm{~nm}$ for $3 \mathrm{~min}$ at $15 \mathrm{~s}$ interval. The activity was calculated using the extinction co-efficient of $6.3 \mathrm{mM}^{-1} / \mathrm{cm}$.

Complex II (Succinate-CoQ Oxidoreductase) Complex II activity was measured by adopting the method given by Hatefi and Stiggall (1978) with slight modification. To $20 \mu \mathrm{l}$ of $1 \mathrm{M}$ sodium succinate ( $\mathrm{pH} 7.4$ ), $0.5 \mu \mathrm{l}$ of $0.2 \mathrm{M}$ EDTA (pH 7.0), $20 \mu \mathrm{l}$ of $0.1 \mathrm{M}$ sodium azide, and $800 \mu \mathrm{l}$ of $50 \mathrm{mM}$ potassium phosphate buffer $(\mathrm{pH}$ 7.4) were added and incubated at $37.8{ }^{\circ} \mathrm{C}$ for $10 \mathrm{~min}$. Further, $16 \mu \mathrm{l}$ of $4.65 \mathrm{mM}$ 6-dichlorophenol indophenol and $20 \mu \mathrm{l}$ of $2.5 \mathrm{mM} \mathrm{CoQ}$ were added. To the above mixture, $50 \mu \mathrm{l}$ of $1 / 5$ diluted mitochondrial fraction was added, and the activity was measured at $600 \mathrm{~nm}$ for $3 \mathrm{~min}$ at $15 \mathrm{~s}$ intervals. The activity was calculated using the extinction coefficient of $21 \mathrm{mM}^{-1} / \mathrm{cm}$.

Complex III (CoQ-Cytochrome c Oxidoreductase) Complex III activity was measured by adopting the method of Shimomura et al. (1984) with slight modification. Reduced $\mathrm{CoQ}\left(\mathrm{CoQH}_{2}\right)$ was prepared by adding a small crystal of potassium borohydride to $50 \mu \mathrm{l}$ of $10 \mathrm{mM} \mathrm{CoQ}$ in ethanol. Five aliquots of $0.1 \mathrm{M} \mathrm{HCl}$ were added by gentle mixing until the yellow solution became colorless. $\mathrm{CoQH}_{2}$ was transferred to a fresh tube, avoiding the borohydride crystal followed by the addition of $5 \mu \mathrm{l}$ of $1 \mathrm{M} \mathrm{HCl}$. The final CoQ concentration was recorded. It was stored in ice during the assay. Upon color change, the reduction process was repeated. To $700 \mu \mathrm{l}$ of $25 \mathrm{mM}$ phosphate buffer ( $\mathrm{pH} 7.5$ ) having $25 \mathrm{mM}$ EDTA, $200 \mu \mathrm{l}$ of $0.1 \mathrm{M}$ sodium azide and $20 \mu \mathrm{l}$ of $30 \mathrm{mM}$ cytochrome- $c$ were added. $63 \mathrm{mM} \mathrm{CoQH}_{2}$ was added followed by the addition of $50 \mu \mathrm{l}$ of $1 / 5$ diluted mitochondrial suspension. The reaction values were recorded at $550 \mathrm{~nm}$ for $3 \mathrm{~min}$ at $15 \mathrm{~s}$ interval. The extinction coefficient of $18.5 \mathrm{mM}^{-1} / \mathrm{cm}$ was used for the calculation. 
Complex IV (CCO) Complex IV activity was assayed using the method given by Wharton and Tzagoloff (1964) with slight modification. Reduced cytochrome- $c$ was freshly prepared before each experiment by adding a few grains of sodium borohydride to $10 \mathrm{~g} / \mathrm{l}$ solution of the pigment cytochrome- $c$ in $10 \mathrm{mM}$ potassium phosphate buffer ( $\mathrm{pH} 7.0$ ). Addition of $0.1 \mathrm{M} \mathrm{HCl}$ stabilized the reduced cytochrome$c$ and excess borohydride was removed by centrifugation at $12,000 \times g$ for $4 \mathrm{~min}$. To $2.85 \mathrm{ml}$ of $50 \mathrm{mM}$ phosphate buffer $(\mathrm{pH} 7.0), 100 \mu \mathrm{l}$ of reduced cytochrome- $c$ was added and incubated. To the above mixture, $50 \mu \mathrm{l}$ of $1 / 5$ diluted mitochondrial suspension was added, and the decrease found in the absorbance was measured at $550 \mathrm{~nm}$ for $3 \mathrm{~min}$ at $15 \mathrm{~s}$ interval. The extinction co-efficient of $21.1 \mathrm{mM}^{-1} / \mathrm{cm}$ was used for calculation.

$A C h E$ (EC 3.1.1.7) AChE assay was performed in tissue homogenates according to the method of Ellman et al. (1961). Briefly, 0.075 M acetylthiocholine iodide was added to the reaction mixture containing $0.1 \mathrm{M}$ phosphate buffer, 0.01 M DTNB and appropriate amount of sample to initiate the reaction. The increase in absorbance was followed at $412 \mathrm{~nm}$ for $5 \mathrm{~min}$ at intervals of $0.5 \mathrm{~min}$, and linearity was checked. AChE activity was calculated using molar extinction co-efficient of 5-mercapto-2-nitrobenzoate $\left(13.6 \times 10^{3} \mathrm{M}^{-1} / \mathrm{cm}\right)$, and the results were expressed as " $\mu$ moles of ACh hydrolyzed/min/protein".

Choline Acetyl Transferase (ChAT, EC 2.3.1.195) Cortex tissues were removed from storage at $-20{ }^{\circ} \mathrm{C}$, thawed and homogenized phosphate buffer $\mathrm{pH} 8.0$ and following centrifugation at $10,000 \times g$, ChAT activity was estimated by the method of Morris (1967). A final volume of $1 \mathrm{ml}$ of incubation medium ( $\mathrm{pH}$ 7.5) consisted of $12 \mathrm{mM}$ choline chloride, $300 \mathrm{mM} \mathrm{KCl}, 0.26 \mathrm{mM}$ eserine sulfate, $40 \mathrm{mM}$ phosphate citrate buffer $\mathrm{pH} 7.5,0.35 \mathrm{mM}$ acetyl CoA, and homogenate. After the period of incubation for $15 \mathrm{~min}$ at $37{ }^{\circ} \mathrm{C}$, the $\mathrm{ACh}$ content was estimated by the colorimetric method of Hestrin (1949). Results are expressed as " $\mu$ moles of ACh formed/hr/protein".

Acetylcholine (ACh) The ACh content was determined by the colorimetric method given by Hestrin (1949). To $0.5 \mathrm{ml}$ of tissue homogenate $(10 \%), 2 \mathrm{ml}$ of alkaline hydroxylamine hydrochloride, $1 \mathrm{ml}$ of $4 \mathrm{~N} \mathrm{HCl}$, and $1 \mathrm{ml}$ of $0.37 \mathrm{M}$ ferric chloride were added. The optical density of the sample was measured at $540 \mathrm{~nm}$ in a spectrophotometer against the blank. The blank consisted of $2 \mathrm{ml}$ of distilled water, $2 \mathrm{ml}$ of alkaline hydroxylamine hydrochloride, and $1 \mathrm{ml}$ of diluted $\mathrm{HCl}$ and $1 \mathrm{ml}$ of ferric chloride solution. A standard graph was prepared with $\mathrm{ACh}$, and the values were expressed as " $\mu$ moles of $\mathrm{ACh} / \mathrm{g}$ wet wt. of tissue".
Statistical Analysis

The results are expressed as mean \pm standard deviation (SD) of six observations $(n=6)$ in each group. Differences between treatment groups of same ages were assessed by one-way analysis of variance, ANOVA (Winner 1971) using the SPSS software package for windows version 15.0. Post hoc testing was performed for inter-group comparisons using Bonferroni test at probability $(p)$ value $<0.05$ level of significance. To analyze the interactive effects, three-way ANOVA was carried out and tested by Duncan's test (1955) for multiple comparisons to define the nature of the effect.

\section{Results}

The changes occurred in the activity level of TCA cycle enzymes viz., ICDH, SDH, MDH, CS, FH, and Acn in aging rat $\mathrm{CNS}$ regions upon $\mathrm{CPF}$ toxicity and cold stress at 15 and $20{ }^{\circ} \mathrm{C}$, and their interactive effects shown in Figs. 1, 2, 3 and 4. Figures 5, 6, 7, and 8 represents the changes occurred as a consequence of $\mathrm{CPF}$, cold stress, and their co-exposure on the activities of ETC complexes viz., Complex I (NADHCoQ-oxido-reductase; Fig. 5), Complex II (succinate-CoQoxido-reductase; Fig. 6), Complex III (CoQ-cytochrome- $c$ oxido-reductase; Fig. 7), and Complex IV (CCO; Fig. 8). To ascertain the existence of interdependence between $\mathrm{AChE}$ activity level and forgoing TCA cycle enzyme/ETC complex variables, respective correlation coefficient $(r)$ were also calculated and presented in Tables 5 and 6.

\section{ICDH Activity}

Both, CPF intoxication and cold stress individually and together exhibited a significant $(p<0.05)$ decrease in ICDH activity. Comparatively, neonatal and juvenile rat brain regions presented higher sensitivity $(p<0.05)$ than young adult animals $(p<0.05)$; however, ICDH activity levels decreased significantly in all treatment groups. Further, interaction of $\mathrm{CPF}$ and cold stress at $15^{\circ} \mathrm{C}$ presented a higher percent (\%) suppression in the enzyme activity by intensifying the toxicity when compared to $\mathrm{CPF}$ and cold stress alone and together at $20^{\circ} \mathrm{C}$.

\section{SDH Activity}

Suppressed SDH activity levels observed in both CPF and cold exposure treatment groups indicating significant inhibition in enzyme levels. The three-way ANOVA indicated an interaction between age and cold stress resulting in increased inhibition in all the treatment groups studied. Comparatively neonatal and juvenile rats presented higher inhibition of SDH 

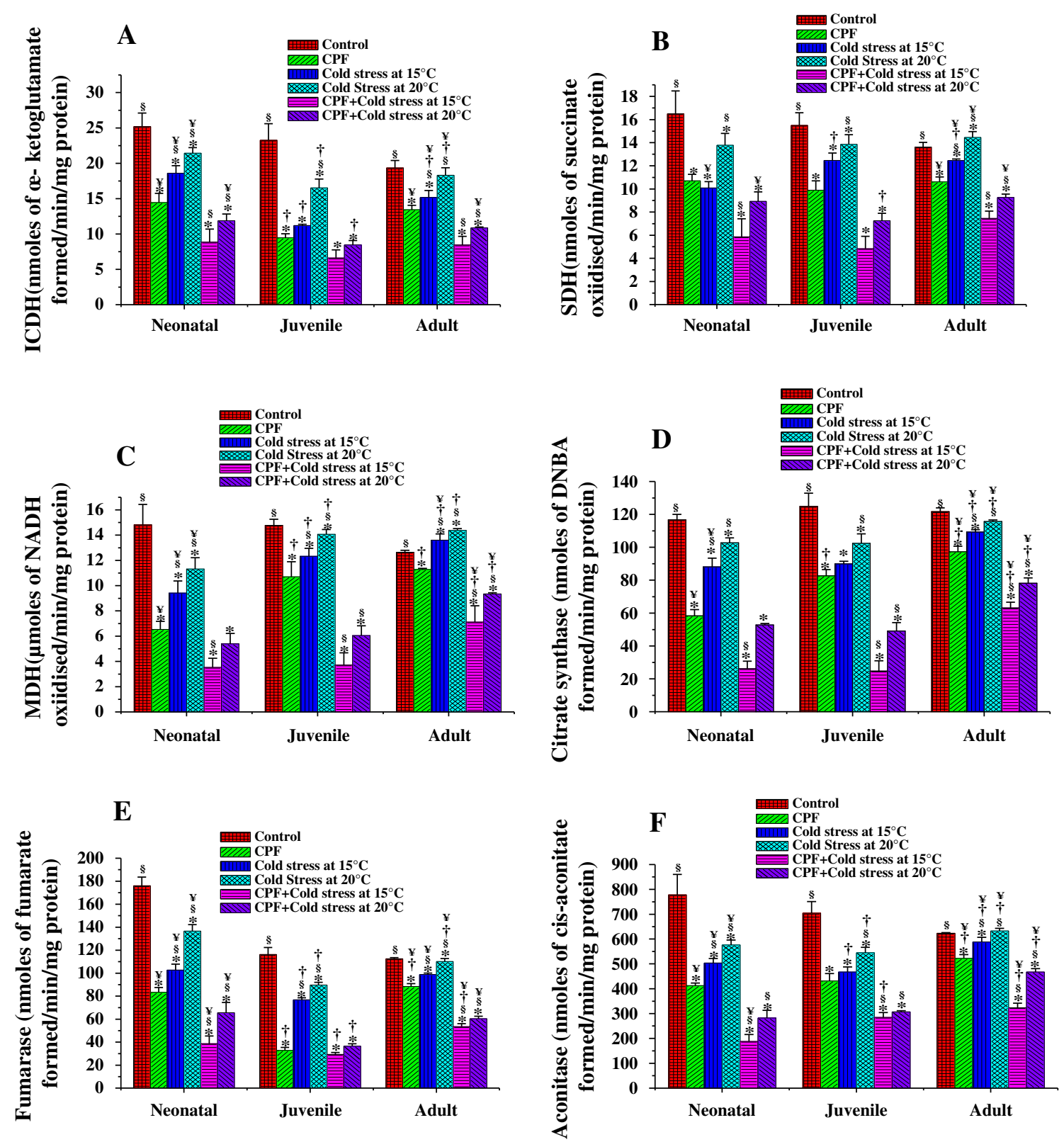

Fig. 1 Interactive effects of $\mathrm{CPF}$ and cold stress on the activity levels of TCA cycle enzymes in the cerebral cortex of different age group rats: a ICDH activity, b SDH activity, c MDH activity, d citrate synthetase activity, $\mathbf{e}$ fumarase activity, and $\mathbf{f}$ aconitase activity. Results are presented as mean $\pm \mathrm{SD}, n=6 .{ }^{*} p<0.05$ significantly

different from control, ${ }^{\S} p<0.05$ significantly different from CPF, ${ }^{\dagger} p<0.05$ significantly different from neonatal in corresponding treatment groups, ${ }^{¥} p<0.05$ significantly different from juvenile in corresponding treatment groups

activity, and these age groups also showed higher sensitivity to combined exposure of $\mathrm{CPF}$ and cold stress at $15{ }^{\circ} \mathrm{C}$.

\section{MDH Activity}

Parallel to SDH inhibition, MDH activity also showed significant inhibition. Both CPF and cold stress individually suppressed the MDH levels while their togetherness at $15{ }^{\circ} \mathrm{C}$ presented higher inhibition than at $20^{\circ} \mathrm{C}$. The threeway ANOVA also indicated an interaction between age

and cold exposure resulting in decreased $\mathrm{MDH}$ levels $(p<0.05)$ while $\mathrm{CPF}$ exposure at $15{ }^{\circ} \mathrm{C}$ modified the toxicity in accelerating MDH inhibition.

\section{CS Activity}

The CS activity significantly $(p<0.05)$ found decreased in experimental rat brain regions upon CPF intoxication and cold stress. In neonatal rat brain, a higher $\%$ decrease observed with regard to CS activity was observed than 

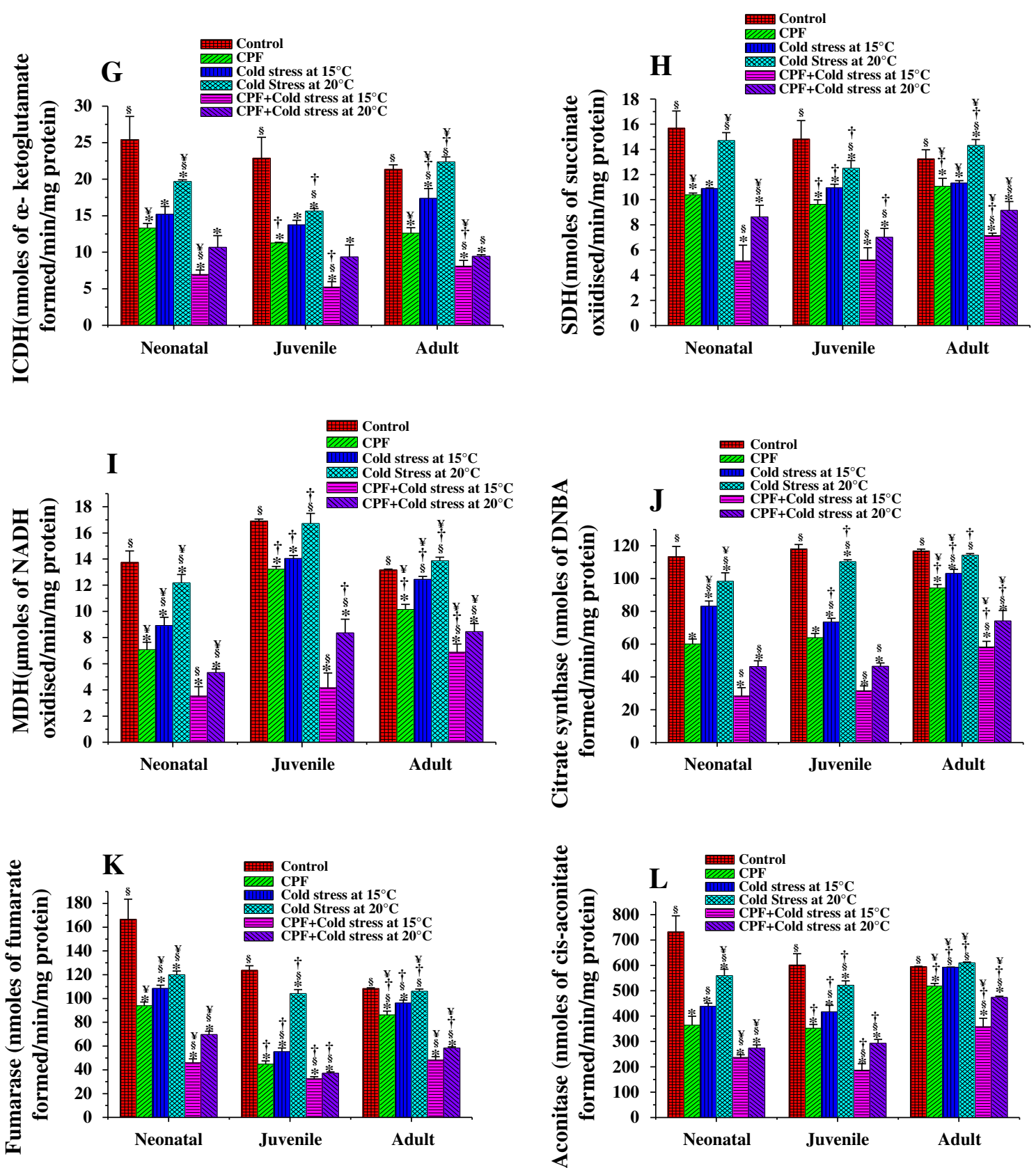

Fig. 2 Interactive effects of CPF and cold stress on the activity levels of TCA cycle enzymes in the cerebellum of different age group rats: g ICDH activity, $\mathbf{h}$ SDH activity, $\mathbf{i}$ MDH activity, $\mathbf{j}$ citrate synthetase activity, $\mathbf{k}$ fumarase activity, and $\mathbf{l}$ aconitase activity. Results are presented as mean $\pm \mathrm{SD}, n=6$. ${ }^{*} p<0.05$ significantly different

juvenile and adult rat brain regions further, cold stress at 15 and $20{ }^{\circ} \mathrm{C}$ appear to deplete the activity levels of CS. In comparison, $15{ }^{\circ} \mathrm{C}$ cold stress caused higher $\%$ suppression by considerably amplifying the toxicity than $20^{\circ} \mathrm{C}$.

Fumarase (FH) Activity

The FH activity levels significantly $(p<0.05)$ depleted in $\mathrm{CNS}$ regions of experimental rats upon $\mathrm{CPF}$

from control, ${ }^{\S} p<0.05$ significantly different from $\mathrm{CPF},{ }^{\dagger} p<0.05$ significantly different from neonatal in corresponding treatment groups, ${ }^{¥} p<0.05$ significantly different from juvenile in corresponding treatment groups

intoxication and cold stress. In juvenile rat brain regions, a higher suppression in fumarase enzyme activity observed when compared to neonatal and young age groups. In this study, when CPF intoxicated rats subjected to cold stress at 15 and $20^{\circ} \mathrm{C}$, a further decrease in the activity level of FH was observed in discrete CNS regions of aging rats. In comparison, $15{ }^{\circ} \mathrm{C}$ cold stress caused higher $\%$ suppression by intensifying the toxicity than $20^{\circ} \mathrm{C}$. 

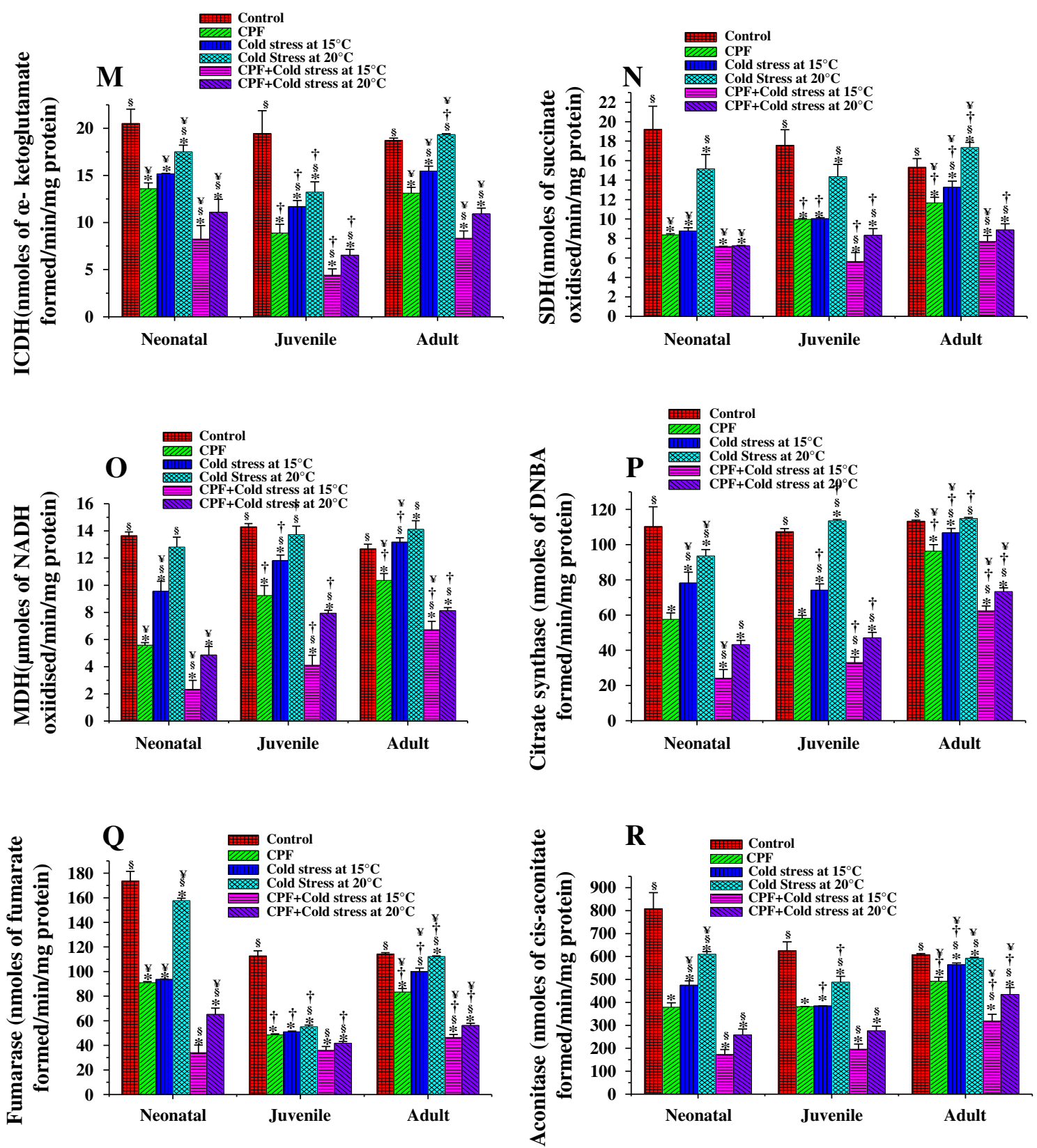

Fig. 3 Interactive effects of CPF and cold stress on the activity levels of TCA cycle enzymes in the medulla oblongata of different age group rats: m ICDH activity, n SDH activity, o MDH activity, $\mathbf{p}$ citrate synthetase activity, $\mathbf{q}$ fumarase activity, and $\mathbf{r}$ aconitase activity. Results are presented as mean $\pm \mathrm{SD}, n=6$. ${ }^{*} p<0.05$

significantly different from control, ${ }^{\S} p<0.05$ significantly different from CPF, ${ }^{\dagger} p<0.05$ significantly different from neonatal in corresponding treatment groups, ${ }^{¥} p<0.05$ significantly different from juvenile in corresponding treatment groups

\section{Acn Activity}

The Acn activity found to be significantly $(p<0.05)$ decreased in discrete CNS regions of experimental rats upon CPF intoxication and cold stress. Comparatively juvenile animals presented higher inhibition than other age groups. In neonatal rat brain, the $\%$ decrease observed upon

CPF intoxication were $-46.93,-50.29,-53.17$, and -41.19 in $\mathrm{CC}, \mathrm{CB}, \mathrm{MO}$, and $\mathrm{SC}$ regions, respectively. Cold stress at 15 and $20{ }^{\circ} \mathrm{C}$ when subjected to $\mathrm{CPF}$ intoxicated rats appear to cause further decrease in the activity level of Acn in discrete CNS regions of aging rats. In comparison, $15^{\circ} \mathrm{C}$ cold stress caused a higher percent suppression by exaggerating the toxicity than $20^{\circ} \mathrm{C}$. 

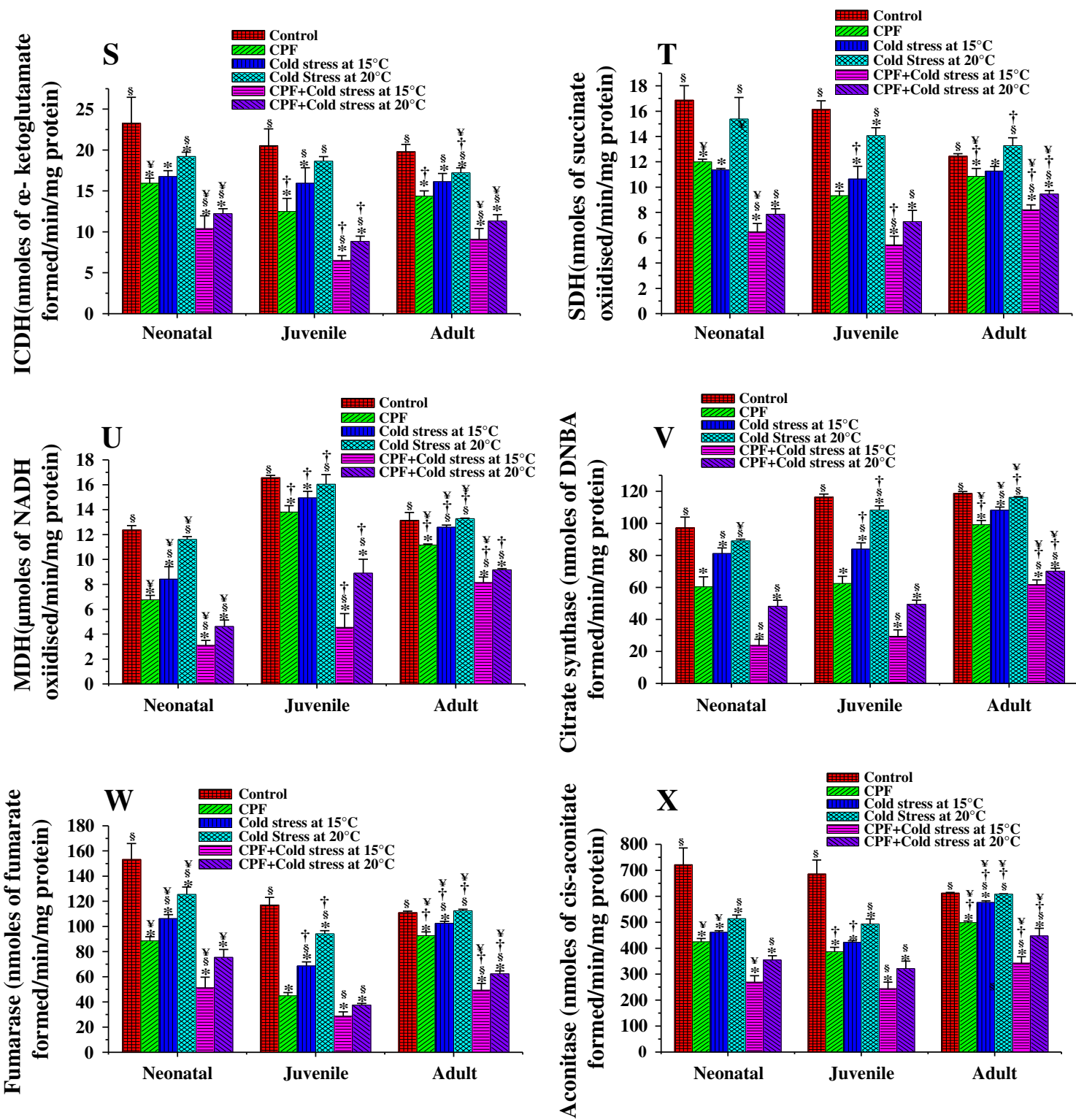

Fig. 4 Interactive effects of CPF and cold stress on the activity levels of TCA cycle enzymes in the spinal cord of different age group rats: $\mathbf{s}$ ICDH activity, $\mathbf{t}$ SDH activity, $\mathbf{u}$ MDH activity, $\mathbf{v}$ citrate synthetase activity, $\mathbf{w}$ fumarase activity, and $\mathbf{x}$ aconitase activity. Results are presented as mean $\pm \mathrm{SD}, n=6$. ${ }^{*} p<0.05$ significantly different

\section{Complex I (NADH-CoQ Oxidoreductase) Activity}

It is clear from the Fig. 5 that CPF toxicity caused a significant inhibition in the activity of Complex I enzyme, while cold exposure (both 15 and $20^{\circ} \mathrm{C}$ ) augmented their levels. When CPF toxicated rats were subjected to cold stress, a severe inhibition in the levels of NADH-CoQ oxidoreductase was observed while exposures at $15{ }^{\circ} \mathrm{C}$ showed higher effect. The three-way ANOVA indicated an interaction between age and cold stress resulting in increased inhibition in all the treatment groups studied.

from control, ${ }^{\S} p<0.05$ significantly different from $\mathrm{CPF},{ }^{\dagger} p<0.05$ significantly different from neonatal in corresponding treatment groups, ${ }^{¥} p<0.05$ significantly different from juvenile in corresponding treatment groups

Comparatively juvenile animals presented higher inhibition than other age groups and $15{ }^{\circ} \mathrm{C}$ cold stress caused higher $\%$ suppression by aggravating the toxicity than $20^{\circ} \mathrm{C}$.

\section{Complex II (Succinate-CoQ Oxidoreductase) Activity}

From the results, it is clear that the activity level of Complex II enzymes markedly $(p<0.05)$ decreased in experimental rat brain tissues upon $\mathrm{CPF}$ intoxication and cold stress. Comparatively juvenile animals presented higher inhibition than other age groups. When cold stress (at 15 and $20{ }^{\circ} \mathrm{C}$ ) 

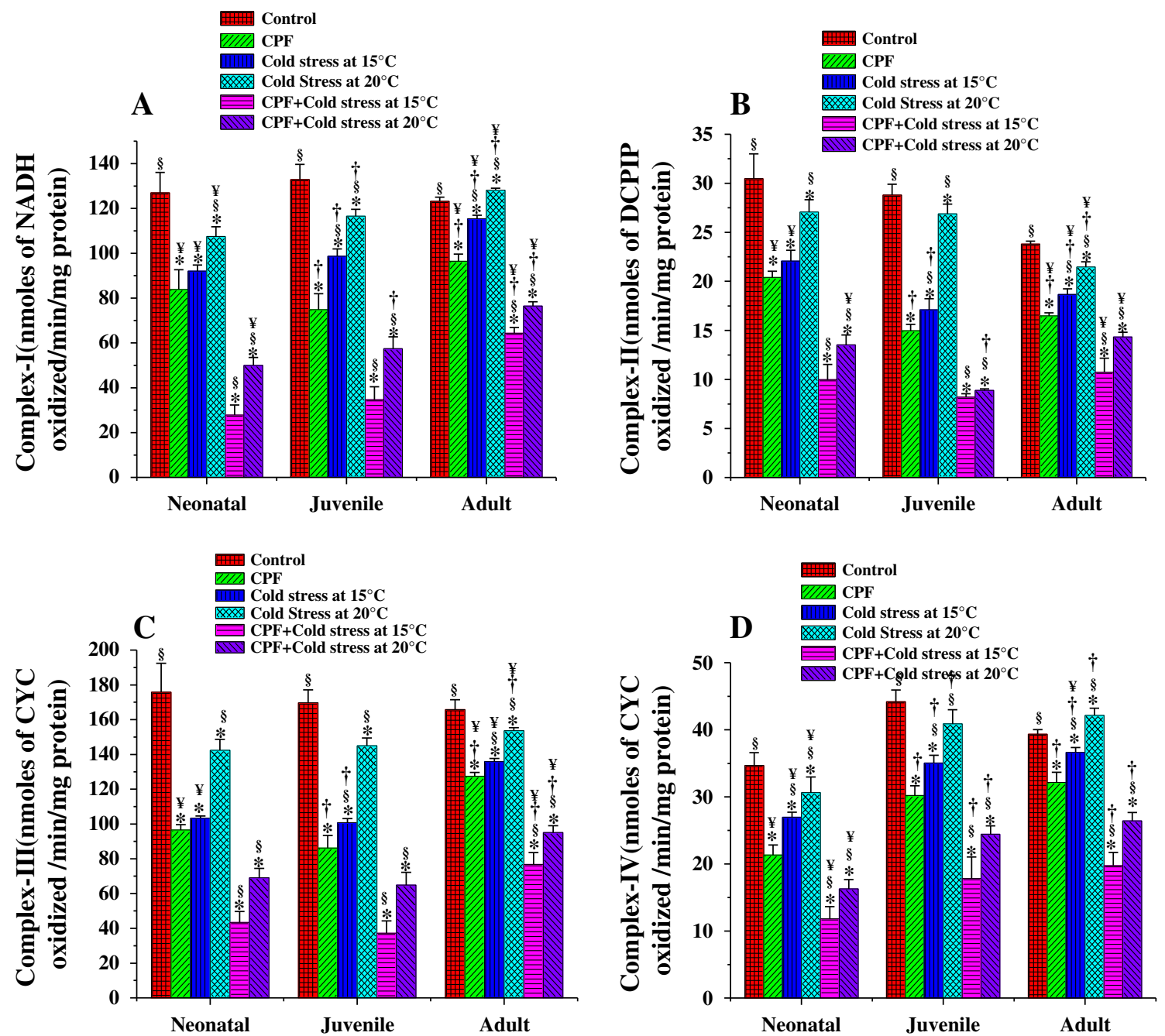

Fig. 5 Interactive effects of CPF and cold stress on the activity levels of ETC complexes in the cerebral cortex of different age group rats: a Complex I, b Complex II, c Complex III, and d Complex IV. Results are presented as mean $\pm \mathrm{SD}, n=6 .{ }^{*} p<0.05$ significantly

different from control, ${ }^{\S} p<0.05$ significantly different from $\mathrm{CPF},{ }^{\dagger}$ $p<0.05$ significantly different from neonatal in corresponding treatment groups, ${ }^{¥} p<0.05$ significantly different from juvenile in corresponding treatment groups

subjected to CPF intoxicated rats, they were appearing to cause further decrease in the activity level of Complex II enzymes. The observed $\%$ decrease upon $15{ }^{\circ} \mathrm{C}$ cold stress to $\mathrm{CPF}$ intoxicated rats were $-67.25,-69.38,-74.07$, and -63.60 in neonatal rats; $-71.56,-68.57,-65.63$, and -63.56 in juvenile rats; $-54.91,-53.83,-53.88$, and -52.78 in young adult rat $\mathrm{CNS}$ regions viz., $\mathrm{CC}, \mathrm{CB}, \mathrm{MO}$, and SC, respectively. In comparison, $15{ }^{\circ} \mathrm{C}$ cold stress caused higher \% suppression by intensifying the toxicity than $20{ }^{\circ} \mathrm{C}$.

\section{Complex III (CoQ-Cytochrome c Oxidoreductase) Activity}

The Complex III enzymes significantly $(p<0.05)$ decreased in rat brain tissues upon CPF intoxication and cold stress. Comparatively neonatal and juvenile rat brain regions presented higher inhibition. Cold stress at 15 and $20{ }^{\circ} \mathrm{C}$ appear

to bring further inhibition in the activity of Complex III enzymes. The observed \% decrease were $-75.28,-75.68$, -81.60 , and -76.72 in neonatal rats; $-78.10,-70.42$, -69.71 , and -69.42 in juvenile rats; $-53.73,-52.77$, -52.30 , and -45.10 in young adult rat $\mathrm{CNS}$ regions viz., $\mathrm{CC}$, $\mathrm{CB}, \mathrm{MO}$, and $\mathrm{SC}$, respectively. In comparison, $15^{\circ} \mathrm{C}$ cold stress caused higher \% suppression by amplifying the toxicity than $20^{\circ} \mathrm{C}$.

\section{Complex IV (CCO) Activity}

The Complex IV enzymes were significantly $(p<0.05)$ decreased in CNS regions of experimental rats upon CPF intoxication and cold stress. Comparatively neonatal and juvenile rat brain regions presented higher inhibition. Cold stress (at 15 and $20^{\circ} \mathrm{C}$ ) when subjected to CPF intoxicated 

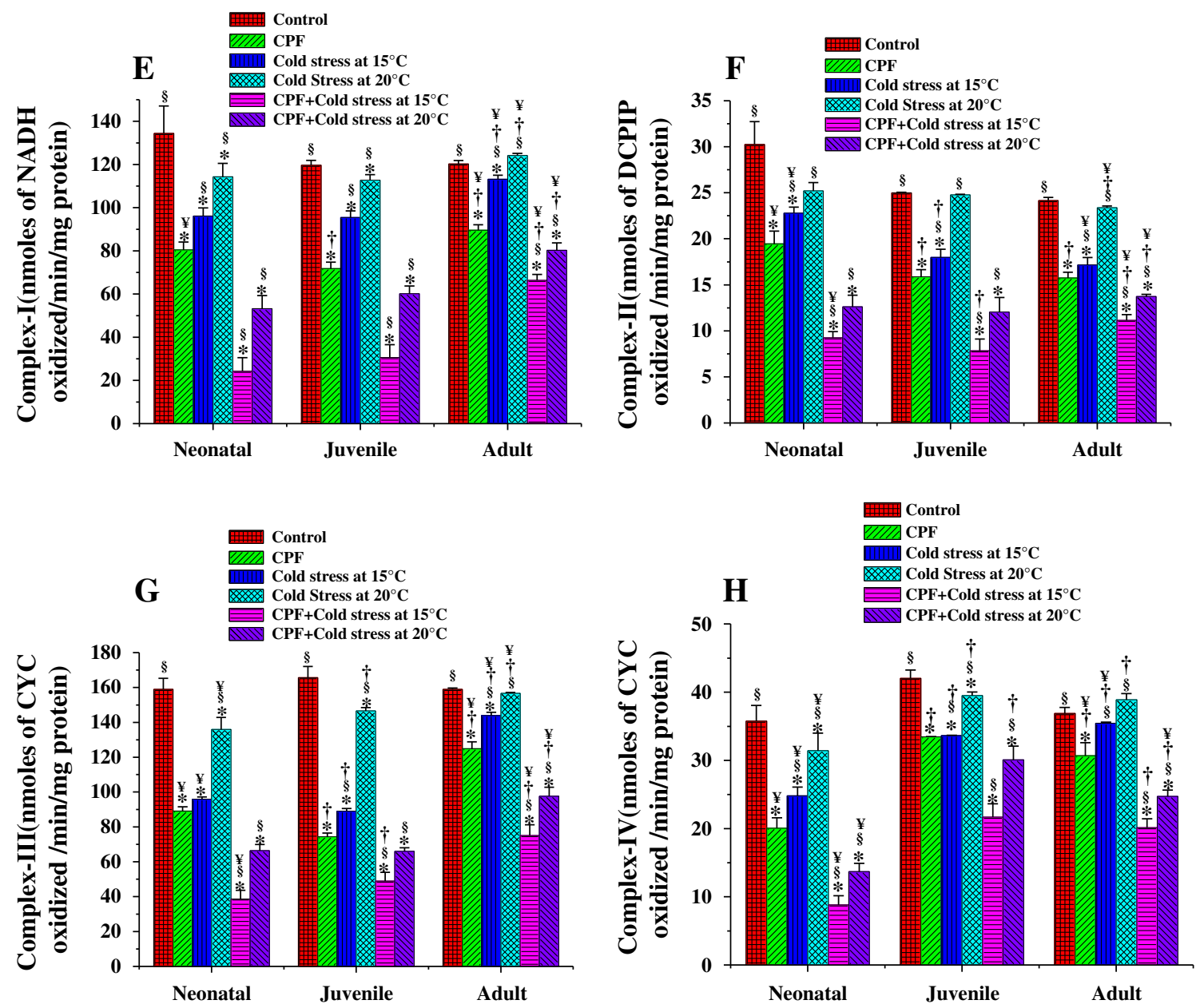

Fig. 6 Interactive effects of CPF and cold stress on the activity levels of ETC complexes in the cerebellum of different age group rats: e Complex I, f Complex II, g Complex III, and h Complex IV. Results are presented as mean $\pm \mathrm{SD}, n=6 . * p<0.05$ significantly different

from control, ${ }^{\S} p<0.05$ significantly different from $\mathrm{CPF},{ }^{\dagger} p<0.05$ significantly different from neonatal in corresponding treatment groups, ${ }^{\ddagger} p<0.05$ significantly different from juvenile in corresponding treatment groups

rats appear to cause further inhibition in the activity level of Complex IV enzymes, and the observed \% inhibition upon $15{ }^{\circ} \mathrm{C}$ cold stress were $-65.93,-75.33,-76.21$, and -70.58 in neonatal rats; $-59.68,-48.46,-60.27$, and -48.47 in juvenile rats; $-49.86,-45.34,-44.88$, and -52.27 in young adult rat $\mathrm{CNS}$ regions viz., $\mathrm{CC}, \mathrm{CB}, \mathrm{MO}$, and SC, respectively. In comparison, $15{ }^{\circ} \mathrm{C}$ cold stress caused higher $\%$ suppression by accentuating the toxicity than $20^{\circ} \mathrm{C}$.

In brief, the activity levels of both TCA cycle and ETC enzymes were significantly $(p<0.05)$ depleted in all age group of rats. Further, co-exposure at 15 and $20{ }^{\circ} \mathrm{C}$ caused significant exacerbation in depleting further loss of TCA cycle enzymes and ETC complexes while severity was evident at $15{ }^{\circ} \mathrm{C}$. In comparison $\mathrm{CB}$ and MO regions of neonatal and juvenile animals showed higher sensitivity $(p<0.05)$ than adult animals $(p<0.05)$.

\section{AChE Activity}

Suppressed AChE activity levels observed in both CPF and cold exposure treatment groups indicating significant inhibition of target enzyme AChE in discrete brain regions (Tables 1, 2, 3, 4). The three-way ANOVA indicated an interaction between age and cold stress resulting in increased inhibition in all the treatment groups studied. Comparatively, neonatal and young adult rats presented higher inhibition of AChE activity, and these age groups also showed higher sensitivity to combined exposure of $\mathrm{CPF}$ and cold stress at $15{ }^{\circ} \mathrm{C}$.

\section{ChAT Activity}

Parallel to AChE inhibition, ChAT activity also showed significant inhibition in all the regions of brain tissues studied (Tables 1, 2, 3, 4). Both CPF and cold stress 

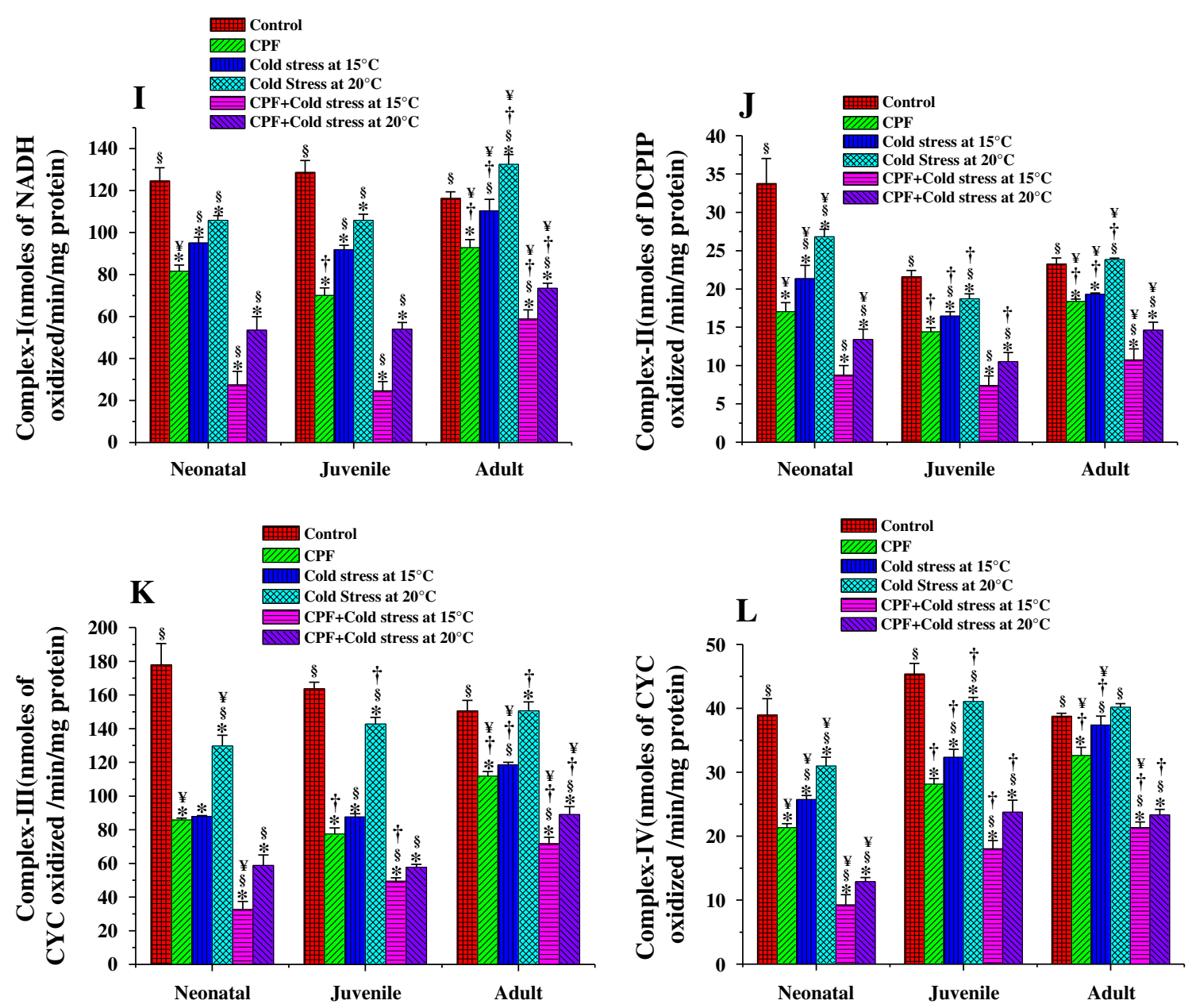

Fig. 7 Interactive effects of $\mathrm{CPF}$ and cold stress on the activity levels of ETC complexes in the medulla oblongata of different age group rats: i Complex I, j Complex II, k Complex III, and l Complex IV. Results are presented as mean $\pm \mathrm{SD}, n=6$. ${ }^{*} p<0.05$ significantly

individually suppressed the ChAT levels while their togetherness at $15{ }^{\circ} \mathrm{C}$ presented higher inhibition than at $20^{\circ} \mathrm{C}$. The three-way ANOVA also indicated an interaction between age and cold exposure resulting in decreased ChAT levels $(p<0.05)$ while $\mathrm{CPF}$ exposure at $15^{\circ} \mathrm{C}$ modified the toxicity in accelerating ChAT inhibition.

\section{Pearson Correlation}

Pearson correlation coefficient $(r)$ assessments were made to evaluate the relation between the AChE activity (marker enzyme for OP pesticides) and the activity levels of TCA cycle enzymes (Table 5). A strong positive correlation $(p<0.01)$ was observed between OP marker enzyme and the activity level of ICDH. The observed " $r$ " values were found to be $+0.831,+0.809$, and +0.866 in $\mathrm{CC} ;+0.910$, +0.957 , and +0.890 in $\mathrm{CB} ;+0.898,+0.906$, and +0.971 in $\mathrm{MO}$, and $+0.881,+0.901$, and +0.798 in SC regions of

different from control, ${ }^{\S} p<0.05$ significantly different from CPF, ${ }^{\dagger} p<0.05$ significantly different from neonatal in corresponding treatment groups, ${ }^{¥} p<0.05$ significantly different from juvenile in corresponding treatment groups

neonatal, juvenile, and young adult rats, respectively. Interactive influence of CPF and cold stress also showed positive correlation between $\mathrm{AChE}$ and SDH activity level, and observed " $\mathrm{r}$ " values were found to be $+0.863,+0.937$, and +0.839 in $\mathrm{CC} ;+0.815,+0.898$, and +0.776 in $\mathrm{CB}$; $+0.961,+0.850$, and +0.937 in MO, and $+0.904,+0.901$, and +0.934 in SC regions of neonatal, juvenile, and young adult rats, respectively.

Likewise a significant positive correlation was evident between AChE and MDH activity level (Table 5), and observed values were $+0.872,+0.952$, and +0.669 in CC; $+0.868,+0.797$, and +0.826 in $\mathrm{CB} ;+0.923,+0.707$, and +0.874 in $\mathrm{MO}$, and $+0.958,+0.932$, and +0.882 in $\mathrm{SC}$ regions of neonatal, juvenile, and young adult rats, respectively. CS activity, as well exhibited a significant positive correlation and the observed " $\mathrm{r}$ " values were $+0.807,+0.967$, and +0.795 in $\mathrm{CC} ;+0.863,+0.923$, and +0.852 in $\mathrm{CB} ;+0.905,+0.711$, and +0.907 in $\mathrm{MO}$, and 

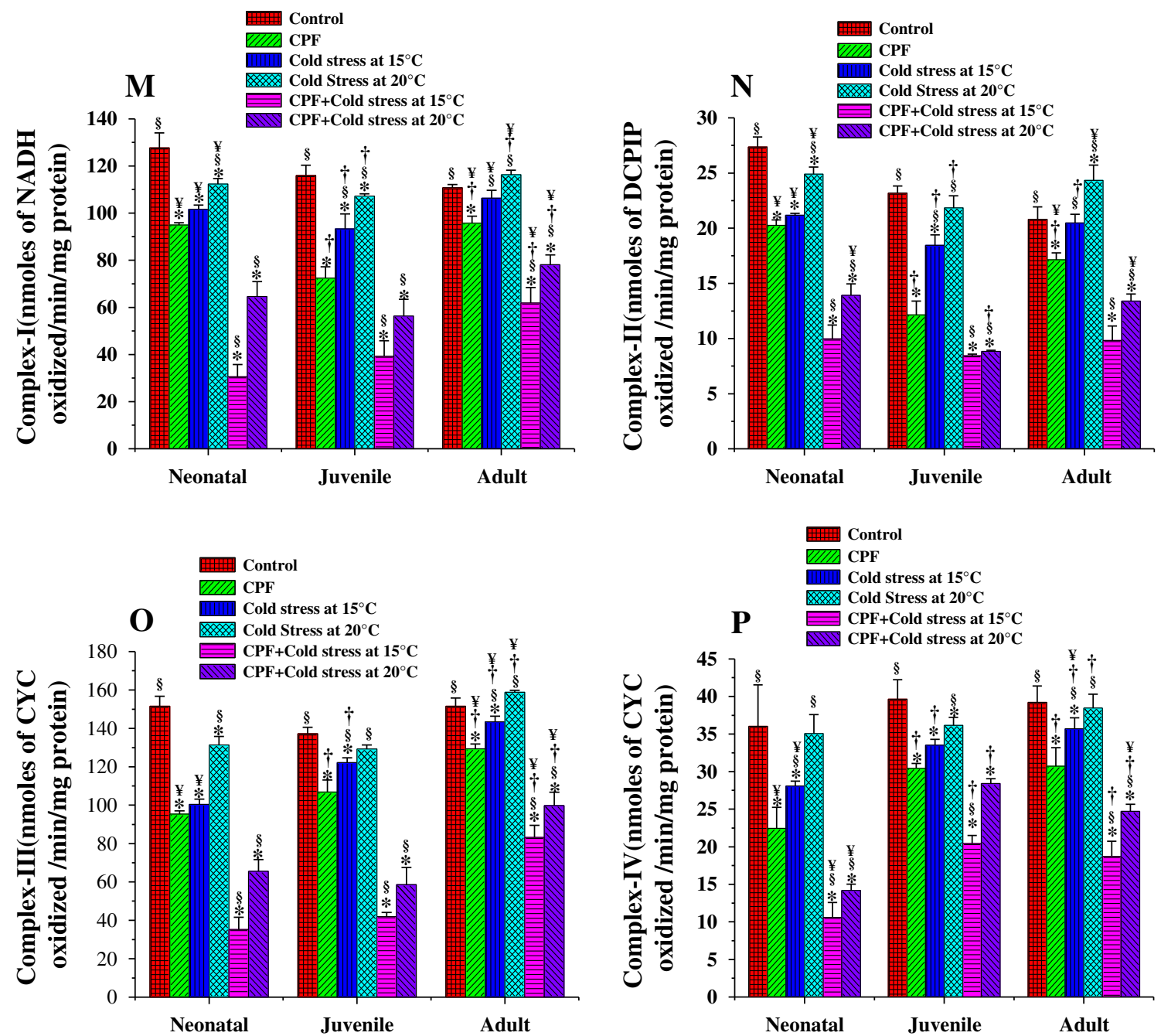

Fig. 8 Interactive effects of CPF and cold stress on the activity levels of ETC complexes in the spinal cord of different age group rats: m Complex I, n Complex II, o Complex III, and p Complex IV. Results are presented as mean $\pm \mathrm{SD}, n=6 .{ }^{*} p<0.05$ significantly

different from control, ${ }^{\S} p<0.05$ significantly different from $\mathrm{CPF}$, ${ }^{\dagger} p<0.05$ significantly different from neonatal in corresponding treatment groups, ${ }^{¥} p<0.05$ significantly different from juvenile in corresponding treatment groups

Table 1 Interactive effects of cold stress (at 15 and $20^{\circ} \mathrm{C}$ ) on the modulation of CPF-induced neurotoxicity in cerebral cortex of aging rats: changes in the activity/level of cholinergic markers

Results are mean $\pm \mathrm{SD}$ of six observations. Values in parenthesis indicate $\%$ change over CPF toxicity. "-" sign indicates decrease, and "+" sign indicates increase

\begin{tabular}{|c|c|c|c|}
\hline Parameters & CPF & $\mathrm{PCPF}+$ cold stress at $15^{\circ} \mathrm{C}$ & $\mathrm{CPF}+$ cold stress at $20^{\circ} \mathrm{C}$ \\
\hline \multicolumn{4}{|c|}{ AChE ( $\mu \mathrm{mol}$ of ACh hydrolysed/min/mg protein) } \\
\hline Neonatal & $16.30 \pm 1.28$ & $8.96 \pm 0.77(-45.03)$ & $11.87 \pm 1.37(-27.17)$ \\
\hline Juvenile & $35.82 \pm 1.73$ & $18.27 \pm 1.58(-48.99)$ & $22.41 \pm 1.55(-37.43)$ \\
\hline Young adult & $41.39 \pm 2.76$ & $34.56 \pm 0.96(-16.50)$ & $36.30 \pm 0.78(-12.29)$ \\
\hline \multicolumn{4}{|c|}{ ChAT ( $\mu$ mol ACh formed/h/mg protein) } \\
\hline Neonatal & $0.43 \pm 0.02$ & $0.23 \pm 0.02(-46.51)$ & $0.30 \pm 0.02(-30.23)$ \\
\hline Juvenile & $0.86 \pm 0.04$ & $0.47 \pm 0.04(-45.35)$ & $0.69 \pm 0.03(-19.77)$ \\
\hline Young adult & $1.91 \pm 0.03$ & $1.47 \pm 0.05(-23.03)$ & $1.78 \pm 0.03(-6.80)$ \\
\hline \multicolumn{4}{|c|}{ ACh ( $\mu \mathrm{mol} \mathrm{ACh/g} \mathrm{wet} \mathrm{weight} \mathrm{of} \mathrm{tissue)}$} \\
\hline Neonatal & $2.31 \pm 0.04$ & $3.77 \pm 0.08(+63.20)$ & $2.64 \pm 0.06(+14.28)$ \\
\hline Juvenile & $6.40 \pm 0.11$ & $8.98 \pm 0.19(+40.31)$ & $7.14 \pm 0.07(+11.56)$ \\
\hline Young adult & $6.78 \pm 0.03$ & $8.12 \pm 0.16(+19.76)$ & $6.86 \pm 0.07(+1.17)$ \\
\hline
\end{tabular}


Table 2 Interactive effects of cold stress (at 15 and $20^{\circ} \mathrm{C}$ ) on the modulation of $\mathrm{CPF}$-induced neurotoxicity in cerebellum of aging rats: changes in the activity/level of cholinergic markers

Results are mean \pm SD of six observations. Values in parenthesis indicate $\%$ change over CPF toxicity. "-" sign indicates decrease, and "+" sign indicates increase

Table 3 Interactive effects of cold stress (at 15 and $20^{\circ} \mathrm{C}$ ) on the modulation of CPF-induced neurotoxicity in medulla oblongata of aging rats: changes in the activity/level of cholinergic markers

Results are mean \pm SD of six observations. Values in parenthesis indicate $\%$ change over CPF toxicity. "-" sign indicates decrease and "+" sign indicates increase

Table 4 Interactive effects of cold stress (at 15 and $20^{\circ} \mathrm{C}$ ) on the modulation of CPF-induced neurotoxicity in spinal cord of aging rats: changes in the activity/level of cholinergic markers

Results are presented as mean $\pm \mathrm{SD}, n=6$. Values in parenthesis indicate \% change over CPF. "-" sign indicates decrease and "+" sign indicates increase

\begin{tabular}{lccc}
\hline Parameters & $\mathrm{CPF}$ & $\mathrm{CPF}+$ cold stress at $15{ }^{\circ} \mathrm{C}$ & $\mathrm{CPF}+$ cold stress at $20{ }^{\circ} \mathrm{C}$ \\
\hline AChE $(\mu \mathrm{mol}$ of $\mathrm{ACh}$ hydrolysed/min/mg & protein) & \\
Neonatal & $18.47 \pm 1.27$ & $5.22 \pm 0.75(-71.73)$ & $7.48 \pm 1.22(-59.50)$ \\
Juvenile & $12.24 \pm 1.41$ & $5.28 \pm 0.83(-56.86)$ & $9.42 \pm 1.38(-23.03)$ \\
Young adult & $46.01 \pm 2.26$ & $34.36 \pm 1.78(-25.32)$ & $43.03 \pm 2.14(-6.47)$ \\
ChAT ( $\mu$ mol of ACh formed/h/mg protein) & \\
Neonatal & $0.46 \pm 0.04$ & $0.18 \pm 0.02(-60.86)$ & $0.28 \pm 0.03(-39.13)$ \\
Juvenile & $0.99 \pm 0.06$ & $0.61 \pm 0.04(-38.39)$ & $0.83 \pm 0.03(-16.16)$ \\
Young adult & $2.30 \pm 0.03$ & $1.35 \pm 0.04(-41.30)$ & $1.79 \pm 0.10(-22.17)$ \\
ACh $(\mu \mathrm{mol}$ of ACh/g wet weight of tissue) & \\
Neonatal & $2.51 \pm 0.08$ & $3.85 \pm 0.13(+53.38)$ & $2.68 \pm 0.05(+6.77)$ \\
Juvenile & $6.56 \pm 0.07$ & $9.02 \pm 0.05(+37.50)$ & $8.45 \pm 0.09(+28.81)$ \\
Young adult & $6.70 \pm 0.06$ & $8.82 \pm 0.13(+31.64)$ & $7.10 \pm 0.33(+5.97)$ \\
\hline
\end{tabular}

\begin{tabular}{|c|c|c|c|}
\hline Parameters & $\mathrm{CPF}$ & $\mathrm{CPF}+$ cold stress at $15^{\circ} \mathrm{C}$ & $\mathrm{CPF}+$ cold stress at $20^{\circ} \mathrm{C}$ \\
\hline \multicolumn{4}{|c|}{ AChE ( $\mu \mathrm{mol}$ of ACh hydrolysed/min/mg protein) } \\
\hline Neonatal & $21.43 \pm 1.07$ & $11.61 \pm 0.96(-45.82)$ & $16.13 \pm 1.17(-24.73)$ \\
\hline Juvenile & $26.43 \pm 1.83$ & $16.29 \pm 1.37(-38.36)$ & $18.73 \pm 1.94(-29.13)$ \\
\hline Young adult & $62.63 \pm 3.22$ & $25.09 \pm 0.74(-59.93)$ & $47.27 \pm 3.52(-24.52)$ \\
\hline \multicolumn{4}{|c|}{ ChAT $(\mu \mathrm{mol}$ ACh formed/h/mg protein } \\
\hline Neonatal & $0.49 \pm 0.04$ & $0.20 \pm 0.02(-59.18)$ & $0.27 \pm 0.03(-44.89)$ \\
\hline Juvenile & $1.03 \pm 0.10$ & $0.64 \pm 0.05(-37.86)$ & $0.88 \pm 0.03(-14.56)$ \\
\hline Young adult & $2.09 \pm 0.04$ & $1.42 \pm 0.03(-32.05)$ & $1.83 \pm 0.03(-12.44)$ \\
\hline \multicolumn{4}{|c|}{ ACh ( $\mu \mathrm{mol} \mathrm{ACh/g} \mathrm{wet} \mathrm{weight} \mathrm{of} \mathrm{tissue)}$} \\
\hline Neonatal & $3.05 \pm 0.09$ & $4.92 \pm 0.08(+61.31)$ & $3.73 \pm 0.07(+22.29)$ \\
\hline Juvenile & $6.69 \pm 0.07$ & $9.27 \pm 0.04(+38.56)$ & $8.22 \pm 0.09(+22.86)$ \\
\hline Young adult & $6.09 \pm 0.12$ & $7.96 \pm 0.55(+30.70)$ & $6.66 \pm 0.31(+9.36)$ \\
\hline
\end{tabular}

$+0.914,+0.919$, and +0.878 in SC regions of neonatal, juvenile, and young adult rats, respectively.

With regard to $\mathrm{AChE}$ and $\mathrm{FH}$ activity level, the observed positive correlation coefficient $(r)$ values in three age group rats (neonatal, juvenile, and young adult) were
$+0.910,+0.859$, and +0.817 in $\mathrm{CC} ;+0.937,+0.952$, and +0.830 in $\mathrm{CB} ;+0.961,+0.991$, and +0.942 in $\mathrm{MO}$ and $+0.935,+0.859$, and +0.888 in $\mathrm{SC}$, respectively. Between AChE and Acn activity levels a similar positive correlation coefficient $(r)$ was observed in all the three age group rats 
Table 5 Correlates of CPF-induced neurotoxicity (AChE) and TCA cycle enzyme activities in discrete CNS regions of aging rats upon $\mathrm{CPF}$, cold stress (at 15 and $20^{\circ} \mathrm{C}$ ), and their co-exposure

\begin{tabular}{|c|c|c|c|c|}
\hline \multirow[t]{2}{*}{ Parameters } & \multirow[t]{2}{*}{ Regions } & \multicolumn{3}{|c|}{ Correlation coefficient $(r)$} \\
\hline & & Neonatal & Juvenile & Adult \\
\hline \multirow[t]{4}{*}{ AChE-ICDH } & $\begin{array}{c}\text { Cerebral } \\
\text { cortex }\end{array}$ & $+0.831 * *$ & $+0.809^{* *}$ & $+0.866^{* *}$ \\
\hline & Cerebellum & $+0.910 * *$ & $+0.957 * *$ & $+0.890 * *$ \\
\hline & $\begin{array}{l}\text { Medulla } \\
\text { oblongata }\end{array}$ & $+0.898 * *$ & $+0.906^{* *}$ & $+0.971 * *$ \\
\hline & Spinal cord & $+0.881 * *$ & $+0.901 * *$ & $+0.798 * *$ \\
\hline \multirow[t]{4}{*}{ AChE-SDH } & $\begin{array}{c}\text { Cerebral } \\
\text { cortex }\end{array}$ & $+0.863^{* *}$ & $+0.937 * *$ & $+0.839 * *$ \\
\hline & Cerebellum & $+0.815^{* *}$ & $+0.898^{* *}$ & $+0.776 * *$ \\
\hline & $\begin{array}{l}\text { Medulla } \\
\text { oblongata }\end{array}$ & $+0.961 * *$ & $+0.850^{* *}$ & $+0.937 * *$ \\
\hline & Spinal cord & $+0.904 * *$ & $+0.901 * *$ & $+0.934 * *$ \\
\hline \multirow[t]{4}{*}{ AChE-MDH } & $\begin{array}{c}\text { Cerebral } \\
\text { cortex }\end{array}$ & $+0.872 * *$ & $+0.952 * *$ & $+0.669 * *$ \\
\hline & Cerebellum & $+0.868 * *$ & $+0.797 * *$ & $+0.826 * *$ \\
\hline & $\begin{array}{l}\text { Medulla } \\
\text { oblongata }\end{array}$ & $+0.923 * *$ & $+0.707 * *$ & $+0.874 * *$ \\
\hline & Spinal cord & $+0.958 * *$ & $+0.932 * *$ & $+0.882 * *$ \\
\hline \multirow[t]{4}{*}{$\begin{array}{l}\text { AChE-citrate } \\
\text { synthase }\end{array}$} & $\begin{array}{c}\text { Cerebral } \\
\text { cortex }\end{array}$ & $+0.807 * *$ & $+0.967 * *$ & $-0.795 * *$ \\
\hline & Cerebellum & $+0.863 * *$ & $+0.923 * *$ & $+0.852 * *$ \\
\hline & $\begin{array}{l}\text { Medulla } \\
\text { oblongata }\end{array}$ & $+0.905^{* *}$ & $+0.711^{* *}$ & $+0.907 * *$ \\
\hline & Spinal cord & $+0.914 * *$ & $+0.919 * *$ & $+0.878^{* *}$ \\
\hline \multirow[t]{4}{*}{$\begin{array}{l}\text { AChE- } \\
\text { fumarase }\end{array}$} & $\begin{array}{l}\text { Cerebral } \\
\text { cortex }\end{array}$ & $+0.910^{* *}$ & $+0.859 * *$ & $+0.817^{* *}$ \\
\hline & Cerebellum & $+0.937 * *$ & $+0.952 * *$ & $+0.830^{* *}$ \\
\hline & $\begin{array}{l}\text { Medulla } \\
\text { oblongata }\end{array}$ & $+0.961 * *$ & $+0.991 * *$ & $+0.942 * *$ \\
\hline & Spinal cord & $+0.935^{* *}$ & $+0.859 * *$ & $+0.888 * *$ \\
\hline \multirow[t]{4}{*}{$\begin{array}{l}\text { AChE- } \\
\text { aconitase }\end{array}$} & $\begin{array}{c}\text { Cerebral } \\
\text { cortex }\end{array}$ & $+0.864 * *$ & $+0.923^{* *}$ & $+0.749 * *$ \\
\hline & Cerebellum & $+0.927 * *$ & $+0.938 * *$ & $+0.750 * *$ \\
\hline & $\begin{array}{l}\text { Medulla } \\
\text { oblongata }\end{array}$ & $+0.939 * *$ & $+0.877 * *$ & $+0.906^{* *}$ \\
\hline & Spinal cord & $+0.899 * *$ & $+0.870 * *$ & $+0.855^{* *}$ \\
\hline
\end{tabular}

** Correlation is significant at the 0.01 level

(neonatal, juvenile, and young adult), and " $\mathrm{r}$ " values observed were $-0.864,-0.923$, and -0.749 in $\mathrm{CC}$; $-0.927,-0.938$, and -0.750 in $\mathrm{CB} ;-0.939,-0.877$, and -0.906 in $\mathrm{MO}$, and $-0.899,-0.870$, and -0.855 in SC regions, respectively (Table 5).

In this study, the occurrence of strong positive correlation $(p<0.01)$ was demonstrated between AChE and the activity level of Complex I (Table 6). The observed "r" values were $+0.782,+0.936$, and +0.813 in $\mathrm{CC} ;+0.864$, +0.877 , and +0.851 in $\mathrm{CB} ;+0.853,+0.808$, and +0.922
Table 6 Correlates of CPF-induced neurotoxicity (AChE) and enzyme activities of ETC complex (I-IV) in discrete CNS regions of aging rats upon $\mathrm{CPF}$, cold stress (at 15 and $20^{\circ} \mathrm{C}$ ) and their coexposure

\begin{tabular}{|c|c|c|c|c|}
\hline \multirow[t]{2}{*}{ Variables } & \multirow[t]{2}{*}{ Regions } & \multicolumn{3}{|c|}{ Correlation coefficient $(r)$} \\
\hline & & Neonatal & Juvenile & Adult \\
\hline \multirow[t]{4}{*}{$\begin{array}{l}\text { AChE- } \\
\text { Complex I }\end{array}$} & $\begin{array}{c}\text { Cerebral } \\
\text { cortex }\end{array}$ & $+0.782 * *$ & $+0.936^{* *}$ & $+0.813^{* *}$ \\
\hline & Cerebellum & $+0.864 * *$ & $+0.877 * *$ & $+0.851 * *$ \\
\hline & $\begin{array}{l}\text { Medulla } \\
\text { oblongata }\end{array}$ & $+0.853^{* *}$ & $+0.808^{* *}$ & $+0.922 * *$ \\
\hline & Spinal cord & $+0.861 * *$ & $+0.919 * *$ & $+0.884^{6 * *}$ \\
\hline \multirow[t]{4}{*}{$\begin{array}{l}\text { AChE- } \\
\text { Complex II }\end{array}$} & $\begin{array}{c}\text { Cerebral } \\
\text { cortex }\end{array}$ & $+0.811 * *$ & $+0.909 * *$ & $+0.864 * *$ \\
\hline & Cerebellum & $+0.884 * *$ & $+0.886^{* *}$ & $+0.951 * *$ \\
\hline & $\begin{array}{l}\text { Medulla } \\
\text { oblongata }\end{array}$ & $+0.931 * *$ & $+0.789 * *$ & $+0.945^{* *}$ \\
\hline & Spinal cord & $+0.904 * *$ & $+0.854 * *$ & $+0.929 * *$ \\
\hline \multirow[t]{4}{*}{$\begin{array}{l}\text { AChE- } \\
\text { Complex III }\end{array}$} & $\begin{array}{c}\text { Cerebral } \\
\text { cortex }\end{array}$ & $+0.894 * *$ & $+0.914 * *$ & $+0.834 * *$ \\
\hline & Cerebellum & $+0.885 * *$ & $+0.947 * *$ & $+0.842 * *$ \\
\hline & $\begin{array}{l}\text { Medulla } \\
\text { oblongata }\end{array}$ & $+0.949 * *$ & $+0.846^{* *}$ & $+0.973 * *$ \\
\hline & Spinal cord & $+0.925^{* *}$ & $+0.919 * *$ & $+0.905^{* *}$ \\
\hline \multirow[t]{4}{*}{$\begin{array}{l}\text { AChE- } \\
\text { Complex IV }\end{array}$} & $\begin{array}{l}\text { Cerebral } \\
\text { cortex }\end{array}$ & $+0.794 * *$ & $+0.940 * *$ & $-0.804 * *$ \\
\hline & Cerebellum & $+0.861 * *$ & $+0.864 * *$ & $+0.795^{* *}$ \\
\hline & $\begin{array}{l}\text { Medulla } \\
\text { oblongata }\end{array}$ & $+0.912 * *$ & $+0.813^{* *}$ & $+0.898 * *$ \\
\hline & Spinal cord & $+0.931 * *$ & $+0.949 * *$ & $+0.861 * *$ \\
\hline
\end{tabular}

** Correlation is significant at the 0.01 level

in $\mathrm{MO}$, and $+0.861,+0.919$, and +0.884 in $\mathrm{SC}$ regions of neonatal, juvenile, and young adult age group rats, respectively. Likewise, a positive correlation was noticed between AChE and Complex II activity level (Table 6), and observed " $\mathrm{r}$ " values were $+0.811,+0.909$ and +0.864 in $\mathrm{CC} ;+0.884,+0.886$, and +0.951 in $\mathrm{CB} ;+0.931$, +0.789 , and +0.945 in $\mathrm{MO}$, and $+0.904,+0.854$, and +0.929 in SC of neonatal, juvenile, and young adult age group rats, respectively. Similarly a significant positive correlation was evident between AChE and Complex III activity level, and observed " $\mathrm{r}$ " values were +0.894 , +0.914 , and +0.834 in $\mathrm{CC} ;+0.885,+0.947$, and +0.842 in $\mathrm{CB} ;+0.949,+0.846$, and +0.973 in $\mathrm{MO}$, and +0.925 , +0.919 , and +0.905 in SC regions of neonatal, juvenile, and young adult rats, respectively. Moreover Complex IV activity exhibited a similar positive correlation, and observed " $\mathrm{r}$ " values were $+0.794,+0.940$, and +0.804 in $\mathrm{CC} ;+0.861,+0.864$, and +0.795 in $\mathrm{CB} ;+0.912,+0.813$, and +0.898 in MO; and $+0.931,+0.949$, and +0.861 in SC regions of neonatal, juvenile, and young adult rats, respectively (Table 6 ). 


\section{Discussion}

Being major production centres of ROS, mitochondria are the key contributors to neurodegenerative disorders. Most of the intracellular ATP is known to be generated in the mitochondria; therefore, toxic insults causing mitochondrial dysfunction may deplete ATP production, leading to excessive generation of ROS. Studies of Liu et al. (2003) reported that accumulation of excessive radicals in mitochondria pave way for oxidative damage resulting in neuronal dysfunction. In our previous communication (Basha and Poojary 2011), we have reported CPF-induced region specific vulnerability wherein both CPF and cold stress (15 and $20{ }^{\circ} \mathrm{C}$ ) cause oxidative stress variably, and their interaction exert a different degree of influence on enzymatic and non-enzymatic antioxidants in different age group of rats, thereby exacerbates the oxidative damage to a greater extent. The results indicated an interaction with age and cold exposure resulting in marked decrease in the activity levels of SOD $(p<0.05)$, CAT $(p<0.05)$, GPx $(p<0.05)$, GST $(p<0.05)$, followed by increased MDA $(p<0.05)$ and decreased GSH levels $(p<0.05)$. The ANOVA and post hoc analysis showed that antioxidant enzymes decreased significantly $(p<0.05)$ on CPF exposure. Moreover synergistic action of $\mathrm{CPF}$ and cold stress at $15^{\circ} \mathrm{C}$ caused higher inhibition on comparison with $\mathrm{CPF}$ and cold stress alone and together at $20^{\circ} \mathrm{C}$ indicating the extent of peroxidative damage in discrete regions of CNS. Further results showed young individuals to be more sensitive than adults. In this study, decreased activities of TCA enzymes followed by suppressed mitochondrial electron transport complexes were evident in all the four CNS regions of aging rats upon $\mathrm{CPF}$ and cold exposure.

\section{Effect on TCA Cycle Enzymes}

The CNS requires a high energy supply due to its intense ATP consumption (Frey et al. 2006). Since neurons utilize glucose as their primary energy source, it follows that the effective functioning of the TCA cycle is essential. Impaired functioning of key enzymes of TCA cycle has been described in OP-poisoning mitochondrial dysfunction models (Tripathi et al. 2003). In the present study, a significant inhibition in the level of TCA cycle enzymes was observed in discrete regions of aging rats studied upon CPF, cold stress and their co-exposure.

\section{Succinate Dehydrogenase}

$\mathrm{SDH}$ is an iron-sulfur containing enzyme. Being a membrane-bound component of the citric acid cycle and also a component of the ETC, SDH participates in transferring electrons to ETC and prone to inactivating by the action of superoxide radicals (Gardner et al. 1994). SDH also plays an important role in regulating osmoregulation, and any change in its activity would disrupt the osmoregulatory mechanism. SDH activity has been reported to be declined during pesticide induced mitochondrial oxidative stress (Kamboj et al. 2008). A significant reduction of SDH observed in this study may be due to non-competitive inhibition exerted by CPF-Oxon which binds to enzyme outside on its active centre of enzyme. Since the supply of succinate for Complex II is dependent on preceding NADlinked dehydrogenase in the TCA cycle; therefore, any alteration in the activity of SDH or Complex II could affect the TCA cycle thereby limit the generation of NADH. Therefore, the decrease found in the activity of SDH in discrete regions in aging animals in this study indicates decline in enzyme synthesis, since CPF disrupt the membrane-bound enzymes. Congruent with these findings, earlier studies of Narra et al. (2012) also reported similar decrease in SDH activity in different tissues of fish Clarias batrachus and fresh water field crab Barytelphusa guerini exposed to $\mathrm{CPF}$.

\section{ICDH Activity}

$\mathrm{ICDH}$ has been shown to play a major role in the oxidative decarboxylation of isocitrate in the TCA cycle. Acn catalyzes the inter conversion of citrate and isocitrate in the TCA cycle, a reaction essential to normal metabolic function. It is the most sensitive enzyme to $\mathrm{H}_{2} \mathrm{O}_{2}$ in the TCA cycle since it contains $\mathrm{Fe}-\mathrm{S}$ clusters in its active site (Tretter and Adam-Vizi 2000). Similarly, oxidative modifications of fumarate and CS resulted in the decrease in their activities. In this study, Krebs cycle enzymes viz., ICDH, Asn, FH were significantly lowered upon toxic insults to both $\mathrm{CPF}$ and cold stress, suggesting a decrease in cellular metabolic rate in neuronal tissues of aging rats. OP pesticides are known to inhibit directly the glycolytic and Krebs cycle enzymes, as in the case of cellular energy producing enzymes (Kamboj et al. 2008). In this study, both CPF and cold stress induced mitochondrial oxidative stress as well as lipid peroxidation would have resulted in modification or adducts formation with ICDH thereby inactivating the enzyme's active sites and might have also impaired the oxidative decarboxylation of isocitrate. Thus the results suggest that $\mathrm{CPF}$ and cold stress affect the compartments of Krebs cycle in aging rat neuronal tissues and alter their metabolic functions to meet the required energy requirements under toxic stress conditions. Congruent with our findings, studies of Tripathi et al. (2003) have reported that OP pesticides like dimethoate inhibit the Krebs cycle enzyme system in fishes thereby diminishes the rate of respiratory process resulting in decreased synthesis of ATP. 


\section{Effect on ETC Complexes}

The mitochondrial ETC comprising of several enzyme complexes is responsible for production of energy, in the form of ATP, which is utilized by the cell (Vali et al. 2007). It has been shown that during normal cellular metabolism, $1-2 \%$ of the electrons which flow into the ETC catalyze(s) the incomplete reduction of $\mathrm{O}_{2}$ to superoxide radical (Boveris and Chance 1973). Available literature indicates that the generation of ROS significantly increases when the function of the ETC are impaired due to toxic insults (Lenaz et al. 2002). The decrease found in the activity levels of respiratory chain enzymes in the present study could be due to decrements of oxygen metabolism and may result in cellular hypoxia in addition to abnormal production of free radicals. It appears that CPF being lipophilic, has the ability to cross biological membranes causing a significant detrimental effect on enzymes of complexes I and IV which are embedded in the mitochondrial membrane. Plethora of studies indicate that mitochondria are susceptible to oxidative stress and free radicals (ROS) generated during the electron transfer in the respiratory complexes might lead to deposition of these radicals in mitochondria that might impinge on its physiology (Lenaz et al. 2002). Unlike other organs, neuronal cells of brain cannot tolerate to high levels of ROS burden for long time, perhaps upon reaching a threshold level of ROS (accumulation), the normal membrane might become leaky and vulnerable to undergo degeneration. Neuronal cells are endowed with low level of antioxidant enzymes and molecules; however, under the condition of enhanced LPO due to toxic insults by CPF, cold stress exposures and their interaction might have caused disruptions in the levels of protective molecules resulting in impaired neuronal integrity. Previous studies emphasizing the decrease in the activities of respiratory chain enzymes and an increase in the ROS level on exposure to OP pesticide corroborate the present study findings (Binukumar et al. 2010; Masoud et al. 2009). Since the ETC complexes are membranebound and sensitive to the lipid microenvironment (Keller et al. 1997), oxidative damage to the inner mitochondrial membrane would have an adverse impact on the enzyme activities of ETC. Specific examples of mitochondrial alterations associated with lipid peroxidation caused by oxidative stress include mitochondrial swelling, decreased trans-membrane potential, uncoupling of oxidative phosphorylation, and depression of CCO activity (Sokol et al. 1991). Previous works of Bolanos et al. (1996) have attributed the decrease in brain GSH to be a major cause for the decrease found in mitochondrial respiratory chain complex activity and signified their sensitivity to cellular antioxidant status. Oxidation of mitochondrial protein by ROS is found to affect the respiratory enzymes (Forsmark-
Andree et al. 1997). In this study the decrease in the activities of TCA cycle enzymes were observed in discrete brain regions of aging rats. This decrease in the activities of ET complexes in turn affected the ATP synthesis.

\section{Influence of Age and Region}

Preponderance of studies has demonstrated that OPs exert untoward effects during critical periods of brain maturation, including altered development of neurotransmitter systems such as cholinergic, catecholaminergic, and seratonergic neurons (Aldridge et al. 2005). Earlier studies have also shown that juvenile rats are highly susceptible to the high-dose toxicity of OP insecticides, and a lack of maturation in detoxification pathways appears to be a contributing factor (Atterberry et al. 1997). The results of this study demonstrated that CPF-intoxication inhibits mitochondrial enzymes in discrete regions of brain, which is influenced by age and cold stress through the generation of free radicals. Young animals were unique because of the immature nervous system which responded differentially to the coupled actions of CPF and cold stress with altered kinetic ability (absorption, distribution, metabolism, and excretion). The greater neonatal sensitivity observed in aging rats primarily could be due to the lack of complete metabolic competence (Benke and Murphy 1975). Lesser detoxification has often been reported to contribute to higher sensitivity of young animals to OP insecticide toxicity (Mortensen et al. 1996). The results of this study signifies that young animals are significantly more vulnerable and sensitive than adults, and there was a gradual decrease in sensitivity to CPF toxicity as the rat matures; thereby the findings of this study corroborate with earlier reports (Moser and Padilla 1998). It can be suggested further that the greater sensitivity of neonatal and juvenile animals may also be due to lower detoxification ability, specifically with respect to carboxylesterases and A-esterases; thus, a higher toxicity has been witnessed in these animals.

The brain tissue being heterogeneous with a large number of different neuronal and non-neuronal cell types, different regional activities of antioxidant systems and variable metabolic rates have led to a region-specific accumulation of oxidative damage, and such differences would have increased the vulnerability of specific brain regions to age-dependent oxidative stress. A high rate of oxygen consumption coupled with low potential of brain to obviate oxidative stress might be the main triggering factor for the enhanced release of ROS during CPF exposure which might have paved the way for mitochondrial dysfunction. In this study, most affected regions of brain in aging rats were found to be $\mathrm{CB}$ followed by $\mathrm{MO}$ and $\mathrm{SC}$ found to be least affected. Results from numerous enzyme 
activity measurements provide a strong support for the hypothesis that brain mitochondria are very heterogeneous with respect to their enzyme contents, and that the enzyme activities differ among brain regions (Cardozo-Palaez et al. 2000).

Interactive Effect(s) of CPF and Cold Stress and Possible Mechanism

Exposure of OP pesticides poses the threat of hypothermia, as they lower body temperature (Rattner and Franson 1984). Cold stress too cause enzymatic alterations and hypothermia in animals, leading to a sequence of metabolic perturbations originated from it (Rajman et al. 2006; Smith and Hoijer 1962). In the present study, when different age group of animals exposed to CPF toxicity at the temperatures of 15 and $20{ }^{\circ} \mathrm{C}$, their interaction exacerbated resulting in a synergistic action that substantially modified the toxicity in discrete brain regions indicating severe effect of $\mathrm{CPF}$ and the quantum of synergistic interaction was most apparent at $15{ }^{\circ} \mathrm{C}$. Since mitochondria are the major source of ROS generation and the target organ dysfunction by inducing oxidative damage, and mitochondrial dysfunction which might work together in a destructive manner to impair the normal functions by increasing further ROS production. The escalation of ROS production eventually leads to neuronal cell death. Hence CPF intoxication triggered ROS production might play a critical role in this vicious circle due to hypothermic action(s) of insecticide and cold exposure. It appears that the induced oxidative stress as a result of CPF and cold stress exposure and their interaction leads to CNS mitochondrial dysfunction via decreased ATP production and increased free radical production. It is also known that the elevation of ROS, RNS, and LPO products acts as non-specific activations of glutamate triggered excitotoxicity in discrete brain regions.

$\mathrm{CPF}$ is bio-activated to its neurotoxic metabolite, CPFOxon, and elicits toxicity through inhibition of AChE. Activity of $\mathrm{AChE}$ is vital for the functioning of cholinergic system and represents a prime target on which some toxicants can exert a detrimental effect (Moussa et al. 2008). Similarly, ChAT activity provides insight into the potential rate of ACh biosynthesis and is often used as a prototypical marker for functional cholinergic neurons (Moussa et al. 2008). It is clear from the present study that CPF exerts an imbalance in neuro-chemical homeostasis resulting in AChE inhibition (Tables 1, 2, 3, 4). The inhibition of AChE activity disturbs the metabolic and neuronal activities and also causes deformities of cell membrane (Moussa et al. 2008). Decreased AChE activity observed following $\mathrm{CPF}$ exposure in the present study is in agreement with the earlier report (Moussa et al. 2008), while decreased ChAT activity levels in this study on exposure to CPF could be related to changes in high affinity of choline uptake as a result of oxidative stress. Supporting the findings of this study, Slotkin et al. (2001) observed a similar reduction in ChAT activity in rodents on post natal day 30 and 60 following subcutaneous exposure of CPF. In this study, a strong positive correlation was observed between maker enzyme, AChE and the level of TCA enzymes/ETC complexes which indicate that the depletion of AChE activity intensifies reduction in the activity potential of TCA/ETC enzymes by inducing cholinergic toxicity. In the present study, Pearson's correlation coefficient values, $r$ (Tables 5, 6) also suggests a considerable depletion in the activity level of mitochondrial enzymes that cause deleterious functional alterations in the aging rat brain, resulting in neurodegeneration and impaired metabolism.

\section{Conclusion}

In summary, the results of this study demonstrate that CPF, cold stress and their interaction induce oxidative stress thereby cause changes in cascade of reactions in mitochondria enzymes and ET system. The disturbance found in the level(s) of mitochondrial enzyme complexes (I-IV) and decrements in the activities of TCA enzymes which were noted in discrete brain regions of aging rats upon $\mathrm{CPF}$ and cold stress exposure. Further, these impairments in mitochondrial functions may responsible for the production of ROS and impaired antioxidant defense system. The changes in the enzyme activities may differentially modulate the brain and SC neural excitability. There exist a strong positive correlation between AChE activity and the TCA enzymes/ETC complexes which emphasizes a close relationship between AChE activity and TCA enzymes/ETC complexes. It is to be noted that simultaneous exposure to a combination of $\mathrm{CPF}$ and cold stress would cause synergistic effect on non-target animals and is considered to be more dangerous than to an exposure of either alone. Furthermore, the present study demonstrates suppression in mitochondrial respiratory enzyme activities which are more profound in neonates and juveniles than the young adults indicating a gradual decrease in sensitivity to CPF toxicity as the rat matures to young adulthood.

Acknowledgments This study was supported by University Grant Commission (UGC), South Western Regional Office, PK Block, Palace Road, Bangalore-560009, India under the Faculty Improvement Programme (FIP) provided for second author.

Conflict of interest The authors declare that they have no conflict of interest.

\section{References}

Aldridge JE, Levin ED, Seidler FJ, Slotkin TA (2005) Developmental exposure of rats to chlorpyrifos leads to behavioral alterations in 
adulthood, involving serotonergic mechanisms and resembling animal models of depression. Environ Health Perspect 113:527-531

Ambali S, Akanbi D, Igbokwe N, Shittu M, Kawu M, Ayo J (2007) Evaluation of subchronic chlorpyrifos poisoning on hematological and serum biochemical changes in mice and protective effect of vitamin C. J Toxicol Sci 32:111-120

Atterberry TT, Burnett WT, Chambers JE (1997) Age-related differences in parathion and chlorpyrifos toxicity in male rats: Target and non-target esterase sensitivity and cytochrome P450mediated metabolism. Toxicol Appl Pharmacol 147:411-418

Basha PM, Poojary A (2011) Chlorpyrifos induced region specific vulnerability in rat CNS and modulation by age and cold stress: an interactive study. Neurochem Res 36:241-249

Basha PM, Poojary A (2012) Oxidative macromolecular alterations in the rat central nervous system in response to experimentally coinduced chlorpyrifos and cold stress: a comparative assessment in aging rats. Neurochem Res 37:335-348

Benke GM, Murphy SD (1975) The influence of age on the toxicity and metabolism of methyl parathion and parathion in male and female rats. Toxicol Appl Pharmacol 31:254-269

Binukumar BK, Bal A, Kandimalla R, Sunkaria A, Gill KD (2010) Mitochondrial energy metabolism impairment and liver dysfunction following chronic exposure to dichlorvos. Toxicology 270:77-84

Bolanos JP, Heales SJR, Peuchen S, Barker JE, Land JM, Clark JB (1996) Nitric oxide-mediated mitochondrial damage: a potential neuroprotective role for glutathione. Free Radic Biol Med 21:995-1001

Boon PE, Van der Voet H, Van Raaij MT, Van Klaveren JD (2008) Cumulative risk assessment of the exposure to organophosphorus and carbamate insecticides in the Dutch diet. Food Chem Toxicol 46:3090-3098

Boveris A, Chance B (1973) The mitochondrial generation of hydrogen peroxide. General properties and effect of hyperbaric oxygen. Biochem J 134:707-716

Cardozo-Palaez F, Brooks PJ, Stedeford T, Songs S, Sanchezramos J (2000) DNA damage, repair and antioxidant systems in brain regions: a correlative study. Free Radic Biol Med 28:779-785

Du F, Zhu X, Zhang Y, Friedman M, Zhang N, Ugurbil K, Chen W (2008) Tightly coupled brain activity and cerebral ATP metabolic rate. Proc Natl Acad Sci USA 105:6409-6414

Duncan DB (1955) Multiple range and multiple F-tests. Biometrics $11: 1-42$

Eaton DL, Daroff RB, Autrup H, Bridge J, Buffler P, Costa LG, Coyle J, McKhann G, Mobley WC, Nadel L, Neubert D, SchutteHerman R, Spencer PS (2008) Review of the toxicology of chlorpyrifos with an emphasis on human exposure and neurodevelopment. Crit Rev Toxicol S2:1-125

Ellman GL, Courtney KD, Andres V Jr, Featherstone RM (1961) A new and rapid calorimetric determination of acetylcholinesterase activity. Biochem Pharmacol 7:88-95

Finney DJ (1971) Probit analysis, 3rd edn. Cambridge University Press, London, p 333

Forsmark-Andree P, Lee CP, Dallner G, Ernster L (1997) Lipid peroxidation and changes in the ubiquinone content and the respiratory chain enzymes of submitochondrial particles. Free Radic Biol Med 22:391-400

Frey BN, Valvassori SS, Gomes KM, Martins MR, Dal-Pizzol F, Kapczinski F, Quevedo J (2006) Increased oxidative stress in submitochondrial particles after chronic amphetamine exposure. Brain Res 1097:224-229

Gardner PR, Nguyen DH, White CW (1994) Aconitase is a sensitive and critical target of oxygen poisoning in cultured mammalian cells and in rat lungs. Proc Natl Acad Sci USA 91:12248-12252
Hatefi Y (1985) The mitochondrial electron transport and oxidative phosphorylation system. Annu Rev Biochem 54:1015-1069

Hatefi Y, Rieske JS (1967) Preparation and properties of DPNHcoenzyme Q reductase (complex I of the respiratory chain). Methods Enzymol 10:235-239

Hatefi Y, Stiggall DL (1978) Preparation and properties of succinate: ubiquinone oxidoreductase (complex II). Methods Enzymol $53: 21-27$

Hestrin S (1949) The reaction of acetylcholine and other carboxylic acid derivatives with hydroxylamine and its analytical application. J Biol Chem 180:249

Hong JH, Kim HJ, Kim KJ, Suzuki K, Lee IS (2008) Comparison of metabolic substrates between exercise and cold exposure in skaters. J Physiol Anthropol 27:273-281

Ishii N, Senoo-Matsuda N, Miyake K, Yasuda K, Ishii T, Hartman PS, Furukawa S (2004) Coenzyme Q10 can prolong C. elegans lifespan by lowering oxidative stress. Mech Ageing Dev 125:41-46

Kamboj SS, Kumar V, Kamboj A, Sandhir R (2008) Mitochondrial oxidative stress and dysfunction in rat brain induced by carbofuran exposure. Cell Mol Neurobiol 28(7):961-969

Kanarek L, Hill RL (1964) The preparation and characterization of fumarase from swine heart muscle. J Biol Chem 239:4202-4206

Karanth S, Pope C (2000) Carboxylesterase and A-esterase activities during maturation and aging: relationship to the toxicity of chlorpyrifos and parathion in rats. Toxicol Sci 58:282-289

Keller JN, Mark RJ, Bruce AJ, Blanc E, Rothstein JD, Uchida K, Waeg G, Mattson MP (1997) 4-Hydroxynonenal, an aldehydic product of membrane lipid peroxidation, impairs glutamate transport and mitochondrial function in synaptosomes. Neuroscience 80:685-696

King J (1965) The dehydrogenases or oxidoreductases-lactate dehydrogenase. In: Practical clinical enzymology. Nostrand Company Ltd., London, pp 83-93

Lenaz G, Bovina C, D’Aurelio M, Fato R, Formiggini G, Genova ML, Giuliano G, Pich MM, Paolucci U, Castelli GP, Ventura B (2002) Role of mitochondria in oxidative stress and aging. Ann NY Acad Sci 959:199-213

Liu R, Liu IY, Bi X, Thompson RF, Doctrow SR, Malfroy B, Baudry M (2003) Reversal of age-related learning deficits and brain oxidative stress in mice with superoxide dismutase/catalase mimetics. Proc Natl Acad Sci USA 100:8526-8531

Lowry OH, Rosebrough NJ, Farr AL, Randal R (1951) Protein measurement with the Folin phenol reagent. J Biol Chem 193:265-275

Lukaszewicz-Hussain A (2010) Role of oxidative stress in organophosphate insecticide toxicity—short review. Pestic Biochem Physiol 98:145-150

Mackenbach JP, Kunst AE, Looman CW (1992) Seasonal variation in mortality in The Netherlands. J Epidemiol Community Health 46:261-265

Maquire CC, Williams BA (1996) Response of thermal stressed bobwhite to organophosphorus exposure. Rev Environ Health 11:101-117

Masoud A, Kiran R, Sandhir R (2009) Impaired mitochondrial functions in organophosphate induced delayed neuropathy in rats. Cell Mol Neurobiol 29:1245-1255

Mehler AH, Kornberg A, Grisolia S, Ochoa S (1948) The enzymatic mechanism of oxidation-reductions between malate or isocitrate and pyruvate. J Biol Chem 174:961-977

Morris D (1967) The effect of sulphydryl and other disulphide reducing agents on cholinetransferase activity estimated with synthetic acetyl CoA. J Neurochem 14:19-27

Mortensen SR, Chanda SM, Hooper MJ, Padilla S (1996) Maturational differences in chlorpyrifos-oxonase activity may 
contribute to age-related sensitivity to chlorpyrifos. J Biochem Toxicol 11:279-287

Moser VC, Padilla S (1998) Age- and gender-related differences in the time-course of behavioral and biochemical effects produced by oral chlorpyrifos in rats. Toxicol Appl Pharmacol 149:107-119

Moussa CEH, Rusnak M, Hailu A, Sidhu A, Stanley T (2008) Fricke Alterations of striatal glutamate transmission in rotenone-treated mice: MRI/MRS in vivo studies. Exp Neurol 209:224-233

Naithani S, Saracco SA, Butler CA, Fox TD (2003) Interactions among COX1, COX2, and COX3 mRNA-specific translational activator proteins on the inner surface of the mitochondrial inner membrane of Saccharomyces cerevisiae. Mol Biol Cell 14:324-333

Narra MR, Rudra RR, Rajender K (2012) Effects of chlorpyrifos on enzymes as biomarkers of toxicity in Fresh water field crab Barytelphusa guerini. Int J Environ Sci 2(4):2015-2023

Navarro A, Gomez C, Sanchez-Pino MJ, Gonzalez H, Bandez MJ, Boveris AD, Boveris A (2005) Vitamin E at high doses improves survival, neurological performance, and brain mitochondrial function in aging male mice. Am J Physiol Regul Integr Comp Physiol 289:R1392-R1399

Obut TA, Saryg SK, Erdynieva TA, Dement'eva TI (2009) Changes in the thyroid activity and influence of dehydroepiandrosteronesulfate under the cold and not cold influence. Ross Fiziol Zh Im I M Sechenova 95:1234-1241

Racker E (1950) Spectrophotometric measurement of the enzymatic formation of fumaric and cis-aconitic acids. Biochim Biophys Acta 4:211-214

Rajman M, Juráni M, Lamošová D, Máčajová M, Sedlačková M, Koštá L, Ježová D, Výboh P (2006) The effects of feed restriction on plasma biochemistry in growing meat type chickens (Gallus gallus). Comp Biochem Phys A 145:363-371

Rattner BA, Franson JC (1984) Methyl parathion and fenvalerate toxicity in American Kestrels: acute physiological responses and effects of cold. Can J Physiol Pharmacol 62:787-792

Rauh VA, Garfinkel R, Perera FP, Andrews HF, Hoepner L, Barr DB, Whitehead R, Tang D, Whyatt RW (2006) Impact of prenatal chlorpyrifos exposure on neurodevelopment in the first 3 years of life among inner-city children. Pediatrics 118:1845-1859

Richter C, Gogvadze V, Laffranchi R, Schlapbach R, Schweizer M, Suter M, Walter P, Yaffee M (1995) Oxidants in mitochondria: from physiology to disease. Biochem Biophys Acta 1271:67-74

Sahin E, Gumuslu S (2004) Cold-stress-induced modulation of antioxidant defence: role of stressed conditions in tissue injury followed by protein oxidation and lipid peroxidation. Int $\mathbf{J}$ Biometeorol 48:165-171

Shimomura Y, Nishikimi M, Ozawa T (1984) Isolation and reconstitution of the iron-sulfur protein in ubiquinol-cytochrome $c$ oxidoreductase complex. Phospholipids are essential for the integration of the iron-sulfur protein in the complex. J Biol Chem 25:14059-14063

Slotkin TA, Cousins MM, Tate CA, Seidler FJ (2001) Persistent cholinergic presynaptic deficits after neonatal chlorpyrifos exposure. Brain Res 902:229-243

Slotkin TA, Levin ED, Seidler FJ (2006) Comparative developmental neurotoxicity of organophosphate insecticides: effects on brain development are separable from systemic toxicity. Environ Health Perspect 114:746-751

Smith RE, Hoijer DJ (1962) Metabolism and cellular function in cold acclimation. Physiol Rev 42:60

Sokol RJ, Dwereaux M, Khandwala RA (1991) Effect of dietary lipid and vitamin $\mathrm{E}$ on mitochondrial lipid peroxidation and hepatic injury in the bile duct-ligated rat. J Lipid Res 32:1349-1357

Srere PA (1969) Citrate synthase. In: Lowenstein JM (ed) Methods in enzymology, citric acid cycle. Academic Press, New York, pp 3-11

Tretter L, Adam-Vizi V (2000) Inhibition of Krebs cycle enzymes by hydrogen peroxide: a key role of a-ketoglutarate dehydrogenase in limiting NADH production under oxidative stress. J Neurosci 20:8972-8979

Tripathi PK, Srivastava VK, Singh A (2003) Toxic effects of dimethoate (organophosphate) on metabolism and enzyme system of freshwater teleost fish Channa punctatus. Asian Fish Sci 16:349-359

Vali S, Mythri RB, Jagatha B, Padiadpu J, Ramanujan KS, Andersen JK, Gorin F, Bharath MM (2007) Integrating glutathione metabolism and mitochondrial dysfunction with implications for Parkinson's disease: a dynamic model. Neuroscience 149:917-930

Vrbacky M, Drahota Z, Mracek T, Vojtiskova A, Jesina P, Stopka P, Houstek J (2007) Respiratory chain components involved in the glycerophosphate dehydrogenase-dependent ROS production by brown adipose tissue mitochondria. Biochim Biophys Acta 1767:989-997

Wharton DC, Tzagoloff A (1964) Studies on the electron transfer system. LVII. The near infrared absorption band of cytochrome oxidase. J Biol Chem 239:2036-2041

Winner BJ (1971) Statistical principles in experimental design, 2nd edn. McGraw-Hill, New York, p 617 